\title{
Heritability and Correlation among Sugarcane (Saccharum spp.) Yield and Some Agronomic and Sugar Quality Traits in Ethiopia
}

\author{
Esayas Tena1 ${ }^{*}$, Firew Mekbib'2, Amsalu Ayana ${ }^{3}$ \\ ${ }^{1}$ Sugar Corporation of Ethiopia, Research and Training, Wonji, Ethiopia \\ ${ }^{2}$ School of Plant Sciences, Haramaya University, Haramaya, Ethiopia \\ ${ }^{3}$ Integrated Seed Sector Development Ethiopia Program, Addis Ababa, Ethiopia \\ Email: "esutena11@gmail.com, firew.mekbib@gmail.com, ayana6a@yahoo.com
}

Received 5 March 2016; accepted 19 July 2016; published 22 July 2016

Copyright (C) 2016 by authors and Scientific Research Publishing Inc.

This work is licensed under the Creative Commons Attribution International License (CC BY). http://creativecommons.org/licenses/by/4.0/

\section{(c) (i) Open Access}

\section{Abstract}

To assess broad sense heritability and phenotypic and genetic correlations among sugarcane yield components, an experiment was conducted at Wonji and Metehara Sugar Estates of Sugar Corporation of Ethiopia during 2012/2013. High broad sense heritability $\left(h^{2}\right)$ was detected for stalk diameter $(0.730)$, single cane weight $(0.672)$, millable cane number $(0.624)$, stalk height $(0.624)$ and pol \% (0.608), indicating that these traits could be selected for easily. Expected genetic gain of the yield components was moderate to high. All traits had low to high genetic correlations $\left(r_{g}=\right.$ -0.005 to 0.884$)$ with cane yield and $\left(r_{g}=0.027\right.$ to 0.999$)$ with sugar yield. On average genetic correlations were higher than phenotypic correlations. High Genotypic Coefficient of Variation (GCV), broad sense heritability and expected genetic advance were recorded for stalk diameter, single cane weight and millable cane number. A selection strategy based on these traits could lead to improvement in cane and sugar yield.

\section{Keywords}

Ethiopia, Heritability, Genetic Correlation, Genetic Advance, Sugarcane

\section{Introduction}

Sugarcane varieties in commercial cultivation are complex polyploid. The heterozygous and polyploid nature of ${ }^{*}$ Corresponding author.

How to cite this paper: Tena, E., Mekbib, F. and Ayana, A. (2016) Heritability and Correlation among Sugarcane (Saccharum spp.) Yield and Some Agronomic and Sugar Quality Traits in Ethiopia. American Journal of Plant Sciences, 7, 1453-1477. 
this crop has resulted in generation of greater genetic variability. The information on the nature and the magnitude of variability present in the genetic material is of prime importance for a breeder to initiate any effective selection program.

In Ethiopia, as in other tropical counties, sugarcane is the major raw material used for sugar production. Sugarcane has been cultivated in the country mainly for chewing purpose in the backyards of small holder farmers since ancient times. Commercial sugarcane cultivation in Ethiopia started in 1954 at Wonji on 5000 ha. At present sugarcane is cultivated on 37,000 ha and the four sugar mills in different parts of the country produce about 300,000 ton sugar per annum. However, this production does not satisfy the domestic consumption, and thus the deficit is being offset by importing sugar from abroad. To bridge the gap between supply and demand as well as to exploit the international market, besides expanding the existing ones, Ethiopia is in the course of establishing new sugar factories with large tract of sugarcane plantation with the aim of attaining production of 2.25 million tons sugar and 181 million litres of ethanol at the end of the year 2014/15 [1].

Since the start the sugar industry of Ethiopia has been relying on importation of sugarcane varieties from many source countries to satisfy the varietal requirements of the sugarcane plantations. So far more than 300 sugarcane varieties has been imported and preserved in germplasm conservation garden located at Wonji. Importing variety per se is not an easy task. Moreover, all the introduced varieties may not become successful commercial cultivars. There is luck of information on these imported varieties vis a vis pedigree, identity of the varieties, etc., which is very difficult to trace as many of the clones are of old generation and significant number are of unknown sources. In spite of a long history of the varieties since introduced no systematic effort has been made to understand the morphogenetic behaviour of traits of these cultivars.

To alleviate the problem of varietal requirement of the industry the Ethiopian Sugar Corporation is now determined to establish sugarcane breeding program to develop its own sugarcane varieties. In any breeding program collection of germplasm is always the first step as it provides plant breeders with sources of useful traits. Especially collecting local germplasm and land races would be crucial as they provide locally adapted genes for better crop improvement. Towards this effort, exploration and collection of local sugarcane germplasm in different geographic regions of the country has been conducted and more than 200 materials were collected and preserved [2].

Information about the nature and the magnitude of variability present in these germplasm collections (introduced and locals) is of paramount importance for their efficient management and effective utilization in the future sugarcane breeding program of Ethiopia.

In sugarcane, the cane and sugar yields are considered to be the complex characters. The information on the phenotypic and genotypic interrelationship of cane yield and sugar yield with their component characters would be of immense help to the sugarcane breeder. Understanding the associations between traits is of great importance in breeding and selection studies especially for low heritability or difficulty in measuring traits [3] [4]. Consideration of genetic relationships between important attributes in exploiting genetic populations through breeding and directed selection is essential, primarily to understand how changes made by selecting one character may cause changes in others [5] [6]. This knowledge can be used when devising appropriate selection strategies for particular traits in a sugarcane breeding program [7]. Number of millable stalks, stalk height and stalk diameter were reported to be positively associated with cane yield [8] [9]. Reference [10] studied phenotypic associations between yield and its components in sugarcane and concluded that selecting for stalk number, diameter and length should be emphasized in sugarcane variety development programs where high cane yield was the primary goal.

The breeder also requires information on the nature and magnitude of genetic variability in the material available. Heritability estimates, together with expected genetic gain, are more useful than the heritability values alone in predicting the effects of selecting the best genotypes. Reference [11] reported high heritability and genetic gain for single cane weight followed by number of millable cane indicating substantial scope for cane yield improvement. On the other hand, sucrose content recorded low heritability and genetic gain suggesting little scope for improvement in this character [12]. In their program, [13] found moderate heritability estimates for length of stalk (0.41), diameter of stalk (0.51) and number of millable stalks (0.53) and significant positive genetic correlations between yield and the three traits. However, it should be remembered that the magnitude of heritability and association among traits is peculiar to the type of population and environments in which they are evaluated [14].

Genotypic Coefficient of Variation (GCV) is another measure of relative genetic variation of a trait in a pop- 
ulation [15]. Traits exhibiting relatively high GCV estimates may respond favorably to selection. Reference [16] reported high GCV for single stalk weight and millable cane.

Genotype $\times$ Environment $(\mathrm{G} \times \mathrm{E})$ interactions are a serious concern in breeding programs as they affect selection decisions. When the rank of a genotype changes across environments it necessitates evaluation of genotypes across the environments to determine their real value [17]. Studies in various sugarcane breeding programs have reported significant $\mathrm{G} \times \mathrm{E}$ interactions for cane and sugar yield [17]-[19].

Since breeding of sugarcane in Ethiopia is in its inception, information on genetic parameters and the relationships among cane yield and its components is crucial for effective selection strategy. The study was therefore conducted to estimate heritability of sugarcane yield and some of its components, and to determine phenotypic and genetic correlations among sugarcane yield components.

\section{Materials and Methods}

\subsection{Description of the Study Sites and Plant Material}

\subsubsection{Site description}

The experiment was conducted at Wonji and Metehara Sugar Estates during 2012/2013 cropping season.

\section{Wonji}

Wonji Sugar Estate is located in Oromia Regional Government State, Eastern Shewa Zone, Adama Woreda, About $110 \mathrm{~km}$ from Addis Ababa and about $10 \mathrm{~km}$ south of Adama Town with latitude $8^{\circ} 31^{\prime} \mathrm{N}$ and longitude $39^{\circ} 12^{\prime} \mathrm{E}$ with elevation of 1550 masl. The average annual rainfall is $800 \mathrm{~mm}$ with maximum and minimum temperatures $26.9^{\circ} \mathrm{C}$ and $15.3^{\circ} \mathrm{C}$ respectively.

\section{Metehara}

Metehara sugar Estate is located in Oromia Regional Government State, Eastern Shewa Zone about $200 \mathrm{Km}$ from Addis Ababa and about $8 \mathrm{~km}$ south of Metahara Town with latitude and longitude $8^{\circ} 51^{\prime} \mathrm{N}$ and $39^{\circ} 52^{\prime} \mathrm{E}$ respectively and with elevation of 950 masl. Annual rainfall is $554 \mathrm{~mm}$ with temperature maximum and minimum of $32.6^{\circ} \mathrm{C}$ and $17.5^{\circ} \mathrm{C}$ respectively.

\subsubsection{Plant Materials}

The plant materials for this study consisted of a total of 400 accessions of which 174 were local sugarcane genotypes (Appendix 1) collected from different regional states of Ethiopia and 226 were introduced sugarcane variety collections (Appendix 2) maintained at conservation garden found at Wonji, Research and Training, Sugar Corporation of Ethiopia. Selection among the local genotypes was made based on geographical regions where the materials were collected and the morphological variations noted during the collection work and when the varieties were quarantined in their collection areas for one year. In exotic/introduced genotypes selection was made taking into consideration the variation in place of origin i.e. source countries and different periods of introductions to the country.

\subsection{Experimental Design and Field Layout}

The experiment was laid out in $20 \times 20$ partial balanced lattice design with two replications. Canes were cut into three budded sets and planted in single row plots of $5 \mathrm{~m} \times 1.45 \mathrm{~m}$ and $20 \mathrm{~cm}$ between plants within a row. Uniform crop management practices were applied to all entries in the trial as recommended for the areas.

\subsection{Data Collected}

Data on quantitative stalk characters and juice quality parameters were recorded vis sprout count 1 and 2 months after planting (SPC1MAP and SPC2MAP), tiller counts 4 and 5 month after planting (TC4MAP and TC5MAP), stalk count 10 months after planting (STC10MAP), millable stalk count per hectare (MSCHA), single cane weight (SCW), number of internodes (NOI), internodes length (IL), stalk height (SH), stalk diameter (SD), leaf length (LL), leaf width (LW), leaf area (LA), cane yield quintal per hectare (CYHA), brix percent (brix \%), pol percent (pol \%), purity percent (purity \%), sugar percent (SR \%) and sugar yield quintal per hectare (SY). For every accession, ten individuals were used for recording data which were recorded on plot basis. Count data and cane yield were recorded considering all cane stalks from the whole plot. 


\subsection{Statistical Analysis}

Combined analysis of variance over two locations was conducted using the general linear model (GLM) procedure of SAS version 9. Estimates of genetic, genotype by environment and error variance components were computed using the VARCOMP procedure of SAS. These components were used to estimate broad-sense heritability [20] [21].

Heritability on genotype mean basis (2 replicates and 2 locations):

$$
h^{2}=\frac{\sigma_{g}^{2}}{\sigma_{p}^{2}}=\frac{\sigma_{g}^{2}}{\sigma_{g}^{2}+\frac{\sigma_{g l}^{2}}{l}+\frac{\sigma_{e}^{2}}{r l}}
$$

where, $\sigma_{g}^{2}=$ genotype, $\sigma_{g l}^{2}=$ genotype $\times$ location $\sigma_{e}^{2}=$ error variances, $r=$ number of replications and $l=$ number of locations.

All variance components were converted to their respective coefficients of variation to allow direct comparisons between traits. Genetic coefficients of variation provide a unit less measure of a trait's genetic variance relative to its mean and permit comparisons among traits with different units and scales and give perspective to available variability to be potentially exploited for genetic gain [8]. The phenotypic coefficient of variation (\%) was calculated as PCV $=100 \sigma_{p}$ phenotypic mean of a trait, and genotypic coefficient of variation as GCV = $100 \sigma_{g}$ /phenotypic mean of a trait.

Expected genetic advance (GA) for each trait was calculated as a proportion of the general mean to allow comparison among traits for potential improvement through selection [8] [22] thus:

$$
\mathrm{GA}=\frac{i \sigma_{p} h^{2}}{\text { phenotypicmeanoftrait }}
$$

where $i=$ selection intensity, $\sigma_{p}=$ phenotypic standard deviation of trait, $h^{2}=$ heritability.

Genetic $\left(r_{\mathrm{g}}\right)$ and phenotypic $\left(r_{\mathrm{p}}\right)$ correlation coefficients and their standard errors were obtained among all the traits by estimating genetic, genotype by environment and error covariances combined across locations using version 9 of SAS Proc Mixed and the REML analysis method based on the variance and covariance components according to [23] as:

$$
r_{i j}=\frac{\sigma_{i j}}{\sigma_{i} \sigma_{j}}
$$

where $r_{i j}=$ phenotypic or genetic correlation coefficient between trait $i$ and trait $j ; \sigma_{i j}=$ genetic or phenotypic covariances between trait $i$ and trait $j ; \sigma_{i}$ and $\sigma_{j}$ are phenotypic or genetic standard deviations of trait $i$ and trait $j$ respectively. Genetic and phenotypic correlations were considered significant if their absolute value was higher than 1.96 times their standard error [24] [25].

\section{Results and Discussion}

Significant $(\mathrm{P}<0.01)$ differences were observed among the genotypes for cane yield, related traits and sugar quality parameters revealing a high level of genetic diversity among them (Table 1). The relatively large genotypic mean squares indicated that clones differed in their potential for the traits. This result indicated that there is significant amount of phenotypic variability and all the genotypes vary each other with regard to the characters that opened a way to proceed for further improvement through simple selection [26] [27]. Genotype $\times$ location interactions were significant for all traits except internodes length. The amount of variation accounted for, ranged from moderate $\left(\mathrm{R}^{2}=0.59\right)$ for internodes length to high $\left(\mathrm{R}^{2}=0.81\right)$ for cane yield. Studying on thirteen sugarcane clones [11] on the other hand reported moderate $\mathrm{R}^{2}$ value for cane yield. This variation might be due to the large number of genotypes considered in this study. Highly significant genotype $\times$ location interactions for most of the traits revealed that mean performances of the genotypes were influenced by the locations. This interaction was largely due to changes in the relative ranking of the genotypes across the locations [11]. The relatively higher $\mathrm{CV} \%$ for some of the traits was due to this higher variability of genotype $\mathrm{X}$ location in the performance of the genotypes. This suggests that at this stage evaluating sugarcane genotypes in more locations rather than one may be satisfactory [27] [28]. 
Table 1. Analysis of variance for twenty stalk characters in 400 sugarcane genotypes grown at Wonji and Metehara during 2012/2013.

\begin{tabular}{|c|c|c|c|c|c|c|c|c|c|}
\hline Characters $^{\dagger}$ & Location & Replication & $\begin{array}{c}\text { Block } \\
\text { (Replication) }\end{array}$ & Genotype & $\begin{array}{l}\text { Location * } \\
\text { Genotype }\end{array}$ & Error & Mean & CV (\%) & $\mathrm{R}^{2}$ \\
\hline & (1) & (1) & (19) & (380) & (399) & (780) & & & \\
\hline SPC1MAP & $10.675^{* *}$ & $6.887^{*}$ & $1.102^{\mathrm{ns}}$ & $1.978^{* *}$ & $1.938^{* *}$ & 1.055 & 14.25 & 49.24 & 0.66 \\
\hline SPC2MAP & $386.921^{* *}$ & $20.108^{* *}$ & $1.240^{\mathrm{ns}}$ & $1.498^{* *}$ & $1.237^{*}$ & 1.044 & 28.19 & 35.89 & 0.65 \\
\hline TC4MAP & $567.169^{* *}$ & $23.802^{* *}$ & $0.983^{\mathrm{ns}}$ & $1.875^{* *}$ & $1.237^{* *}$ & 0.957 & 76.45 & 25.27 & 0.71 \\
\hline TC5MAP & $44.092^{* * *}$ & $0.082^{\mathrm{ns}}$ & $0.626^{\mathrm{ns}}$ & $0.953^{* *}$ & $0.919^{* *}$ & 0.559 & 71.42 & 18.63 & 0.65 \\
\hline STC10MAP & $46.119^{* *}$ & $17.248^{* *}$ & $0.372^{\mathrm{ns}}$ & $1.066^{* *}$ & $0.616^{* *}$ & 0.289 & 59.35 & 13.88 & 0.77 \\
\hline MSCHA & $40.712^{* *}$ & $3.074^{* *}$ & $0.409^{*}$ & $1.196^{* *}$ & $0.590^{* *}$ & 0.252 & $88,602.95$ & 4.49 & 0.79 \\
\hline SCW & $1.180^{* *}$ & $3.156^{* *}$ & $0.145^{\mathrm{ns}}$ & $0.517^{* *}$ & $0.166^{* *}$ & 0.123 & 1.52 & 23.12 & 0.74 \\
\hline NOI & $779.806^{* *}$ & $250.431^{* *}$ & $18.531^{\mathrm{ns}}$ & $52.037^{* *}$ & $26.659^{* *}$ & 14.623 & 28.21 & 13.57 & 0.74 \\
\hline $\mathrm{IL}$ & $20.473^{\mathrm{ns}}$ & $1.962^{\mathrm{ns}}$ & $7.351^{\text {ns }}$ & $15.618^{* *}$ & $10.229^{\mathrm{ns}}$ & 9.235 & 8.84 & 34.35 & 0.59 \\
\hline $\mathrm{SH}$ & $88,352.063^{* *}$ & $9279.902^{* *}$ & $640.917^{\mathrm{ns}}$ & $3337.181^{* *}$ & $1243.085^{* *}$ & 872.007 & 240.44 & 12.29 & 0.74 \\
\hline SD & $5.050^{* *}$ & $0.001^{\mathrm{ns}}$ & $0.042^{\mathrm{ns}}$ & $0.337^{* *}$ & $0.089^{* *}$ & 0.060 & 2.66 & 9.18 & 0.79 \\
\hline LL & $8953.181^{* *}$ & $5978.962^{* *}$ & $212.970^{\mathrm{ns}}$ & $526.532^{* *}$ & $359.608^{* *}$ & 189.594 & 127.95 & 10.76 & 0.72 \\
\hline LW & $0.483^{\text {ns }}$ & $27.152^{* *}$ & $0.483^{\mathrm{ns}}$ & $1.844^{* *}$ & $0.792^{* *}$ & 0.622 & 4.29 & 18.39 & 0.69 \\
\hline LA & $132290.602^{* *}$ & $545322.802^{* *}$ & $6137.660^{\mathrm{ns}}$ & $25433.571^{* *}$ & $12832.068^{* *}$ & 9734.180 & 413.46 & 23.89 & 0.68 \\
\hline CYHA & $5,857,126.000^{* *}$ & $7,375,569.600^{* *}$ & $284,712.100^{\mathrm{ns}}$ & $1,667,648.400^{* *}$ & $619,916.600^{* *}$ & $279,325.000$ & 1360.27 & 39.12 & 0.81 \\
\hline Brix\% & $4.364^{\mathrm{ns}}$ & $24.310^{* *}$ & $1.271^{\mathrm{ns}}$ & $5.225^{* *}$ & $2.164^{*}$ & 1.791 & 19.40 & 6.90 & 0.68 \\
\hline Pol\% & $34.281^{* *}$ & $32.627^{* *}$ & $1.499^{\mathrm{ns}}$ & $6.202^{* *}$ & $2.410^{* *}$ & 1.861 & 18.15 & 7.52 & 0.71 \\
\hline Purity\% & $354.399^{* *}$ & $19.678^{\mathrm{ns}}$ & $7.269^{\mathrm{ns}}$ & $13.471^{* *}$ & $8.545^{* *}$ & 6.697 & 93.47 & 2.77 & 0.64 \\
\hline SR\% & $61.297^{* *}$ & $20.338^{* *}$ & $1.036^{\mathrm{ns}}$ & $4.052^{* *}$ & $1.601^{* *}$ & 1.199 & 12.99 & 8.44 & 0.71 \\
\hline SY & $38,976.630^{* *}$ & $79,538.100^{* *}$ & $5466.260^{\mathrm{ns}}$ & $30,595.530^{* *}$ & $11,103.880^{* *}$ & 5298.920 & 178.89 & 41.00 & 0.80 \\
\hline
\end{tabular}

${ }^{\dagger}$ SPC1MAP and SPC2MAP = Sprout count 1 and 2 months after planting; TC4MAP and TC5MAP = Tiller counts 4 and 5 months after planting; STC10MAP = Stalk count 10 months after planting; MSCHA = Millable stalk count per hectare; SCW = Single cane weight (Kg); NOI = Number of internodes; IL = Internodes length $(\mathrm{cm}) ; \mathrm{SH}=$ Stalk height $(\mathrm{cm}) ; \mathrm{SD}=$ Stalk diameter $(\mathrm{cm}) ; \mathrm{LL}=$ Leaf length $(\mathrm{cm}) ; \mathrm{LW}=\mathrm{Leaf}$ width $(\mathrm{cm}) ; \mathrm{LA}=$ Leaf area $\left(\mathrm{cm}^{2}\right)$; CYHA = Cane yield (qt/ha); Brix $\%=$ Brix percent; Pol\% = Pol percent; Purity\% = Purity percent; SR $\%=$ Sugar percent; SY = Sugar yield (qt/ha); ${ }^{* *} \mathrm{P}<0.01 ;{ }^{*} \mathrm{P}=0.05 ; \mathrm{ns}=$ nonsignificant; numbers in parenthesis are degrees of freedom.

\subsection{Estimation of Genotypic and Phenotypic Coefficients of Variation}

The variance components were used to compute heritability estimates in Table 2 [29]. Genetic variance is important as it describes the amount of genetic variation present for the trait. The genetic variance component for all traits exceeded the genotype $\times$ location (Table 2). After partitioning phenotypic variance, it was found that genotypic variance was lower than the environmental one for most of the characters studied except single cane weight and stalk diameter. Genetic and environment variances were similar for single cane weight and stalk diameter. Congruent with the present study [11] studying on fourteen sugarcane clones also reported similar genetic and environment variances for single cane weight and stalk diameter combined over locations and plant and first ratoon crop. These results indicated that a significant role was played by the environmental factors in the inheritance of the characters in sugarcane.

The magnitude of genetic variance was the highest in number of millable canes $\left(\delta_{g}^{2}=838,822,000.00, \delta_{e}^{2}\right.$ $=525,333,966.000)$ followed by cane yield $\left(\delta_{g}^{2}=261,988.00, \delta_{e}^{2}=163,306.500\right)$, sugar yield $\left(\delta_{g}^{2}=4884.90\right.$, $\left.\delta_{e}^{2}=5604.40\right)$ and leaf area $\left(\delta_{g}^{2}=3274.40, \delta_{e}^{2}=9815.80\right)$. The high genotypic variance for millable cane number was reported also by other researchers [30] [31]. In contrast to the present study [16] studying on 32 sugarcane 
Table 2. Combined components of variances, coefficients of variation, heritability and genetic advance for twenty characters in 400 sugarcane genotypes grown at Wonji and Metehara in 2012/2013.

\begin{tabular}{|c|c|c|c|c|c|c|c|}
\hline \multirow{2}{*}{ Characters* } & \multicolumn{3}{|c|}{ Components $^{\dagger}$} & \multirow[b]{2}{*}{ PCV\% } & \multirow[b]{2}{*}{ GCV\% } & \multirow[b]{2}{*}{$h^{2}$} & \multirow[b]{2}{*}{ GA\% } \\
\hline & $\delta_{g}^{2}$ & $\delta_{g l}^{2}$ & $\delta_{e}^{2}$ & & & & \\
\hline SPC1MAP & 0.90 & 45.354 & 131.093 & 52.683 & 6.641 & 0.016 & 1.7 \\
\hline SPC2MAP & 41.51 & 3.517 & 402.379 & 42.554 & 22.859 & 0.289 & 25.3 \\
\hline TC4MAP & 472.01 & 0.000 & 1860.500 & 40.042 & 28.418 & 0.504 & 41.5 \\
\hline TC5MAP & 55.27 & 373.384 & 1143.700 & 32.170 & 10.409 & 0.105 & 6.9 \\
\hline STC10MAP & 262.81 & 197.611 & 436.485 & 36.559 & 27.317 & 0.558 & 42.0 \\
\hline MSCHA & $838,822,000.00$ & $525,333,966.000$ & $973,984,558.000$ & 41.391 & 32.688 & 0.624 & 53.2 \\
\hline SCW & 0.09 & 0.020 & 0.126 & 23.451 & 19.221 & 0.672 & 32.5 \\
\hline NOI & 6.14 & 5.909 & 14.796 & 12.677 & 8.780 & 0.480 & 12.5 \\
\hline IL & 1.39 & 0.455 & 9.317 & 22.457 & 13.319 & 0.352 & 16.3 \\
\hline $\mathrm{SH}$ & 513.14 & 167.716 & 899.992 & 11.924 & 9.421 & 0.624 & 15.3 \\
\hline SD & 0.06 & 0.014 & 0.061 & 10.759 & 9.195 & 0.730 & 16.2 \\
\hline LL & 43.70 & 83.121 & 190.334 & 9.008 & 5.166 & 0.329 & 6.1 \\
\hline LW & 0.26 & 0.079 & 0.634 & 15.775 & 11.879 & 0.567 & 18.4 \\
\hline LA & 3274.40 & 1481.400 & 9815.800 & 19.453 & 13.840 & 0.506 & 20.3 \\
\hline СYHA & $261,988.00$ & $163,306.500$ & $293,369.100$ & 47.472 & 37.628 & 0.628 & 61.4 \\
\hline Brix\% & 0.76 & 0.160 & 1.823 & 5.859 & 4.483 & 0.585 & 7.1 \\
\hline Pol\% & 0.93 & 0.243 & 1.899 & 6.797 & 5.301 & 0.608 & 8.5 \\
\hline Purity\% & 1.14 & 0.860 & 6.806 & 1.936 & 1.145 & 0.349 & 1.4 \\
\hline SR\% & 0.59 & 0.181 & 1.224 & 7.661 & 5.931 & 0.599 & 9.5 \\
\hline SY & 4884.90 & 2749.800 & 5604.400 & 48.927 & 39.070 & 0.638 & 64.3 \\
\hline
\end{tabular}

${ }^{\dagger} \delta_{g}^{2}=$ Genotypic variance; $\delta_{g l}^{2}=$ Genotype $\times$ Location variance; $\delta_{e}^{2}=$ Environment variance; PCV = Phenotypic coefficient of variation; GCV = Genotypic coefficient of variation; $h^{2}=$ Heritability percentage; GA = Genetic advance in percent of mean *Character abbreviations as given in Table 1.

genotypes in Nepal in one environment reported higher genotypic variance over environmental one for cane yield, millable cane number, single cane weight, stalk diameter, stalk length and sucrose percent. The reason for this variation could be the large number of genotypes and more than one environment considered in the present study. Reference [11] also observed in plant cane that the highest magnitude of genetic variance relative to environmental variance was exhibited by number of internodes (151.23\%), millable cane $(143.84 \%)$ and stalk weight (116.31\%) indicating that environmental factors influenced their expression less than the other traits.

Genotypic coefficient of variation (GCV) is another measure of relative genetic variation of a trait in a population [15]. Traits exhibiting relatively high GCV estimates may respond favourably to selection. The estimates for phenotypic coefficient of variation (PCV) were higher than for genotypic coefficient of variation (GCV) in all the traits (Table 2), suggesting that the apparent variation is not only due to genetics but also due to environmental influences. Reference [32] also found higher PCV over GCV for number of millable cane, stalk height, stalk diameter, single cane weight, brix \%, pol \% and cane yield.

The highest phenotypic coefficient of variation were observed for sprout count 1 month after planting (PCV = 52.683) followed by sugar yield $(\mathrm{PCV}=48.927)$ and cane yield $(\mathrm{PCV}=47.472)$. On the other hand the highest genotypic coefficient of variation were observed for sugar yield $(\mathrm{GCV}=39.070)$ followed by cane yield $(\mathrm{GCV}=$ 
37.628) and number of millable cane (GCV = 32.688). High genotypic and phenotypic coefficients of variation for number millable cane were reported earlier [33]. The GCV values for cane yield and its components like single cane weight, number of millable canes, stalk height and diameter were larger than the values for sucrose content (pol \%) and juice brix. Large amount of genetic variation for stalk height and diameter, number of millable canes and hand rifractometer brix reading at active growth stage was reported and concluded that progress in breeding for higher sucrose yield can be made by emphasizing selection for high sucrose content at early ripening stage along with higher cane yield [34] [35].

\subsection{Heritability}

The success of a variety improvement programme depends largely on the amount of genetic variability present in the population. Genotypic coefficient of variation is not a correct measure to know the heritable variation present and should be considered together with heritability estimates. Genetic coefficients of variation along with heritability estimates give a better indication of the amount of genetic variation for a trait than either parameter alone.

In the present study, high heritability estimates were recorded for stalk diameter (0.730), single cane weight (0.672), sugar yield (0.638), cane yield (0.628), millable cane number (0.624), stalk height $(0.624)$ and pol \% (0.608) (Table 2).

Moderate broad sense heritability estimates ranging from 0.599 - 0.480 were found in sugar \%, brix\%, leaf width, stalk count 10 months after planting, leaf area, tiller count 4 months after planting and number of internodes. This suggests that a considerable proportion of the total variance is heritable and selection of these traits would be effective. High heritability estimate for millable cane number (0.88), stalk diameter (0.85) and single cane weight (0.84) was reported [16]. Similarly [11] also reported high heritability for stalk diameter (0.928), number of millable canes (0.912), single cane weight (0.907), number of internodes (0.907) and moderate heritability for cane yield (0.515). However, the heritability values were relatively higher than the present study. The probable cause of the disparity could be due to the fact that the heritability of a given trait refers to a particular population under a particular condition or environment. Moreover the study by [16] was conducted in single environment and considered only 32 sugarcane genotypes. Similarly [11] included only 14 genotypes in their study. High heritability estimate was also reported elsewhere for single cane weight [31] [36]. Low heritability estimates were observed in sprout count 1 and 2 months after planting, tiller count 5 month after planting, internodes length, leaf length and purity \%. Selections might be considerably difficult or virtually impractical for a character with low heritability (less than 0.4 ) due to the masking effect of environment on genotypic effects [37] [38]. Generally the heritability values for the important stalk characters studied were high to moderate paving the way for improvement of these characters through simple selection. Knowledge of variability and heritability of characters is essential for identifying those amenable to genetic improvement through selection [39]. Results of the current study indicate that use of the traits with high heritability as selection criteria together with cane yield could lead to genetic improvement in cane and sugar yield. Under the conditions of this study stalk diameter, single cane weight, sugar yield, cane yield, millable cane number, stalk height and pol \% were reliable selection parameters.

\subsection{Genetic Advance}

The effectiveness of selection depends not only on heritability but also on genetic advance [29] [40]. Heritability estimates along with expected genetic gain is more useful than the heritability value alone in predicting the resultant effect for selecting the best genotypes [41]. As presented in Table 2, maximum genetic gain (as percent of mean) was observed for sugar yield (64.3\%) followed by cane yield (61.4\%), millable cane number (53.2\%), stalk count 10 months after planting (42.0\%), tiller count 4 months after planting (41.5\%) and single cane weight (32.5\%). Greatest genetic advance is also expected in leaf area (20.3\%), leaf width (18.4\%), stalk diameter (16.2\%) and stalk height (15.3\%). The results suggest existence of considerable scope for improvement of these characters by adopting suitable breeding strategy. High genetic advance has also been reported elsewhere for single stalk weight and number of millable cane [42]-[44]. The high genetic gain of these characters was the result of high broad sense heritability and high GCV for these traits [45]. The high broad sense heritability coupled with high genetic advance for these characters indicates these traits are under the control of additive genetic effects and highlights the usefulness of selection based on phenotypic performance [22]. High genetic advance (as percent of 
mean) for millable cane number was also reported by [16] and for cane yield [11]. Moderate heritability with low genetic advance for sugar quality parameters indicate presence of non-additive gene action and therefore simple selection on phenotypic performance may not be effective [22]. Similarly, low genetic advance with low heritability was recorded for sprout count one month after planting, leaf length, tiller count 5 months after planting, number of internodes and inter node length.

The results suggested that selection should be practiced on the basis of stalk diameter, single cane weight and millable cane number for higher cane and sugar yield. These were followed by stalk height, stalk count 10 months after planting, tiller count 4 months after planting, leaf width and leaf area. The same result for single stalk weight followed by number of millable cane and stalk diameter was reported [11]. Similarly, [16] also reported selection should be practiced on the basis of single cane weight and millable cane number for higher cane yield. Reference [46] showed that plant height, cane diameter, leaf area and intermodal distance had positive and significant correlation with millable cane weight that in turn showed a major contribution towards the final cane yield, however cane diameter, height and internode length can be exploited successfully for further and future cane improvement program. They concluded improvement in these traits would lead to a significant improvement in yield in limited selection cycles. Moderate heritability accompanied by low genetic advance for sugar quality parameters indicated that there is little hope for improvement of these traits by simple selection. Similar results for juice quality characters were obtained [16] [42].

The higher broad sense heritability, expected genetic advance and GCV for cane yield and sugar yield indicated that direct selection for these traits seems plausible. Reference [47] have also reported high estimates of broad sense heritability and expected genetic advance for cane and sugar yield.

\subsection{Genotypic and Phenotypic Correlations}

Genotypic and phenotypic correlation matrixes are presented in (Table 3) and (Table 4) respectively. Millable stalk count showed highly significant genetic correlations with tiller count 5 months after planting, stalk count 10 month after planting, single cane weight, stalk diameter, brix percent and significant association with sprout count 2 months after planting. Non significant positive correlation with cane yield, sugar quality parameters and sugar yield was also observed. Similarly, [48] reported significant genetic correlations of number of millable cane with sprout counts, single cane weight and cane yield.

Cane yield had highly significant strong positive genetic correlation with number of internodes, leaf length and width and leaf area and negative significant association with sprout count 1 month after planting and negative non significant correlations with tiller counts and single cane weight. Genetic correlation of cane yield with stalk height, stalk diameter, single cane weight, number of millable stalks and sugar quality traits was positive and non significant. Reference [11] also reported significant positive genetic correlation of cane yield with number of internodes and positive non significant correlation with millable stalk number but in contrast to the present study they found negative and non significant correlation of cane yield with stalk height. Reference [48] also found positive and highly significant genotypic associations of cane yield with single cane weight, number of millable cane per plot, leaf area and germination percent. On the other hand, [13] found in their program significant positive genetic correlations of cane yield with stalk height, stalk diameter and number of millable cane. However, it should be remembered that the magnitude of heritability and association among traits is peculiar to the type of population and environments in which they are evaluated [14]. Moreover the number of genotypes considered in their study and the present work largely varies. More number of genotypes was considered in the current study.

Sugar yield was mainly dependent on number of internodes, stalk diameter, leaf length, pol \%, purity $\%$ and sugar \%. The association with cane yield was positive but nonsignificant. Positive and significant association of sugar yield with cane yield, pol \% and sugar \% was reported [49].

Single cane weight exhibited highly significant strong positive genetic correlation with sprout count 2 months after planting, tiller count 5 month after planting, stalk count 10 month after planting, stalk diameter, number of internodes and brix percent and non significant positive association with cane yield. Negative non significant genetic correlation with internodes length and non significant positive association with other parameters was observed for this trait. Strong positive genetic correlations of single cane weight with number of internodes, stalk diameter and stalk height and non significant positive association with cane yield was reported [11].

Stalk diameter showed highly significant genetic correlation with tiller count 5 month after planting, stalk count 10 month after planting, number of millable cane, single cane weight, number of internodes and brix percent. It 
Table 3. Genetic correlations among 21 phenotypic characters ${ }^{\dagger}$ measured on 400 sugarcane genotypes.

\begin{tabular}{|c|c|c|c|c|c|c|c|c|c|c|c|c|c|c|c|c|c|c|c|c|}
\hline & A & B & C & D & E & $\mathbf{F}$ & G & $\mathbf{H}$ & I & $\mathbf{J}$ & $\mathbf{K}$ & $\mathbf{L}$ & M & $\mathbf{N}$ & $\mathbf{O}$ & $\mathbf{P}$ & $\mathbf{Q}$ & $\mathbf{R}$ & S & $\mathbf{T}$ \\
\hline A & 1.000 & & & & & & & & & & & & & & & & & & & \\
\hline B & $-0.471^{*}$ & 1.000 & & & & & & & & & & & & & & & & & & \\
\hline C & -0.084 & $0.663^{* *}$ & * 1.000 & & & & & & & & & & & & & & & & & \\
\hline D & -0.145 & $0.738^{* *}$ & $0.552^{*}$ & 1.000 & & & & & & & & & & & & & & & & \\
\hline $\mathbf{E}$ & -0.094 & $0.711^{* *}$ & 0.363 & $0.808^{* *}$ & 1.000 & & & & & & & & & & & & & & & \\
\hline $\mathbf{F}$ & 0.104 & $0.529^{*}$ & 0.434 & $0.839^{* *}$ & $0.901^{* *}$ & 1.000 & & & & & & & & & & & & & & \\
\hline G & -0.142 & $0.628^{* *}$ & 0.413 & $0.812^{* *}$ & $0.884^{* *}$ & $0.887^{* *}$ & 1.000 & & & & & & & & & & & & & \\
\hline H & -0.383 & 0.357 & 0.112 & 0.291 & 0.370 & 0.263 & $0.642^{* *}$ & 1.000 & & & & & & & & & & & & \\
\hline I & $-0.490^{*}$ & 0.361 & -0.016 & 50.109 & 0.021 & -0.184 & -0.082 & 0.072 & 1.000 & & & & & & & & & & & \\
\hline $\mathbf{J}$ & 0.239 & 0.146 & 0.402 & 0.231 & 0.242 & 0.342 & 0.357 & 0.230 & -0.408 & 1.000 & & & & & & & & & & \\
\hline $\mathbf{K}$ & 0.014 & 0.412 & 0.259 & $0.633^{* *}$ & $0.760^{* *}$ & $0.778^{* *}$ & $0.887^{* *}$ & $0.690^{* *}$ & -0.108 & 0.376 & 1.000 & & & & & & & & & \\
\hline $\mathbf{L}$ & $-0.515^{*}$ & 0.220 & -0.045 & 0.029 & 0.064 & -0.075 & 0.327 & $0.855^{* *}$ & 0.186 & 0.074 & 0.415 & 1.000 & & & & & & & & \\
\hline $\mathbf{M}$ & -0.275 & 0.188 & -0.105 & 0.152 & 0.289 & 0.123 & 0.293 & $0.454^{*}$ & 0.127 & 0.073 & 0.362 & 0.353 & 1.000 & & & & & & & \\
\hline $\mathbf{N}$ & $-0.470^{*}$ & 0.051 & -0.205 & -0.220 & -0.185 & -0.342 & 0.004 & $0.617^{* *}$ & 0.084 & 0.068 & 0.119 & $0.867^{* *}$ & 0.373 & 1.000 & & & & & & \\
\hline $\mathbf{O}$ & $-0.459^{*}$ & 0.135 & -0.112 & -0.042 & -0.005 & 0.148 & 0.174 & $0.650^{* *}$ & 0.112 & 0.134 & 0.254 & $0.783^{* *}$ & $0.712^{* *}$ & $0.884^{* *}$ & 1.000 & & & & & \\
\hline $\mathbf{P}$ & -0.142 & $0.628^{* *}$ & 0.412 & $0.811^{* *}$ & $0.884^{* *}$ & $0.887^{* *}$ & $1.000^{* *}$ & $0.642^{* *}$ & -0.082 & 0.357 & $0.887^{* *}$ & 0.327 & 0.293 & 0.004 & 0.174 & 1.000 & & & & \\
\hline $\mathbf{Q}$ & 0.131 & 0.154 & 0.128 & 0.211 & 0.238 & 0.175 & 0.441 & $0.646^{* *}$ & 0.024 & 0.117 & $0.513^{*}$ & $0.538^{*}$ & 0.045 & 0.262 & 0.195 & 0.441 & 1.000 & & & \\
\hline $\mathbf{R}$ & 0.109 & 0.163 & 0.122 & 0.197 & 0.209 & 0.143 & 0.419 & $0.645^{* *}$ & 0.052 & 0.106 & $0.490^{*}$ & $0.565^{* *}$ & 0.033 & 0.306 & 0.225 & 0.419 & $0.996^{* *}$ & 1.000 & & \\
\hline S & 0.017 & 0.161 & 0.058 & 0.060 & 0.025 & -0.067 & 0.232 & $0.546^{*}$ & 0.128 & 0.037 & 0.274 & $0.618^{* *}$ & -0.017 & $0.465^{*}$ & 0.331 & 0.232 & $0.861^{* *}$ & $0.901^{* *}$ & 1.000 & \\
\hline $\mathbf{T}$ & 0.094 & 0.170 & 0.118 & 0.189 & 0.192 & 0.123 & 0.405 & $0.643^{* *}$ & 0.068 & 0.098 & $0.474^{*}$ & $0.579^{* *}$ & 0.027 & 0.331 & 0.242 & 0.405 & $0.990^{* *}$ & $0.999^{* *}$ & $0.921^{* *}$ & 1.000 \\
\hline
\end{tabular}

had also significant positive genetic correlations with all sugar parameters and sugar yield but showed nonsignificant correlation with sugar percent. In conformity with this finding [11] also reported significant positive genetic correlation of stalk diameter with number of internodes and single cane weight and non significant association with cane yield. In the present investigation, it is interesting that stem diameter had significant positive association with sugar yield and sugar quality characters indicating the significance of this trait in improving sugar quality traits and sugar yield. Similar reports have been made by earlier sugarcane workers [48] [50] for sugar yield.

Number of internodes had highly significant positive genetic correlations with stalk diameter, single cane weight, leaf length, leaf area, cane yield, brix percent, pol percent, purity percent, and sugar yield while it had significant positive correlation with leaf width and sugar percent and positive non significant association with number of millable cane. Similarly, [11] reported significant positive genetic correlation of number of internodes with stalk diameter and single cane weight and non significant positive association with cane yield. Association with other characters was positive and non significant. Significant association of number of internodes with brix percent, sugar percent and sugar yield was also reported by [48].

Leaf area exhibited highly significant strong positive genetic correlation with number of internodes, leaf length and cane yield and significant correlation with sugar percent while association with other characters was nonsignificant. Reference [48] also found highly significant correlation of this trait with cane yield and sugar percent. 
Table 4. Phenotypic correlations among 21 phenotypic characters ${ }^{\dagger}$ measured on 400 sugarcane genotypes.

\begin{tabular}{|c|c|c|c|c|c|c|c|c|c|c|c|c|c|c|c|c|c|c|c|c|}
\hline & $\mathbf{A}$ & B & C & D & $\mathbf{E}$ & $\mathbf{F}$ & G & $\mathbf{H}$ & I & $\mathbf{J}$ & $\mathbf{K}$ & $\mathbf{L}$ & $\mathbf{M}$ & $\mathbf{N}$ & $\mathbf{O}$ & $\mathbf{P}$ & $\mathbf{Q}$ & $\mathbf{R}$ & S & $\mathbf{T}$ \\
\hline A & 1.000 & & & & & & & & & & & & & & & & & & & \\
\hline B & $-0.288^{* *}$ & $* 1.000$ & & & & & & & & & & & & & & & & & & \\
\hline C & $-0.100^{*}$ & $0.557^{* *}$ & 1.000 & & & & & & & & & & & & & & & & & \\
\hline D & $-0.120^{*}$ & $0.478^{* *}$ & $0.299^{* *}$ & 1.000 & & & & & & & & & & & & & & & & \\
\hline $\mathbf{E}$ & 0.055 & $0.380^{* *}$ & $0.188^{* *}$ & $0.571^{* *}$ & 1.000 & & & & & & & & & & & & & & & \\
\hline $\mathbf{F}$ & $0.131^{* *}$ & $0.278^{* *}$ & $0.220^{* *}$ & $0.615^{* *}$ & $0.587^{* *}$ & 1.000 & & & & & & & & & & & & & & \\
\hline G & -0.063 & $0.356^{* *}$ & $0.231^{* *}$ & $0.581^{* *}$ & $0.532^{* *}$ & $0.833^{* *}$ & 1.000 & & & & & & & & & & & & & \\
\hline H & $-0.279^{* *}$ & $0.177^{* *}$ & 0.075 & $0.120^{*}$ & 0.095 & 0.045 & $0.537^{* *}$ & 1.000 & & & & & & & & & & & & \\
\hline I & $-0.231^{* *}$ & *0.210** & 0.029 & 0.089 & 0.004 & $-0.137^{* *}$ & ${ }^{*}-0.083$ & 0.040 & 1.000 & & & & & & & & & & & \\
\hline $\mathbf{J}$ & $0.182^{* *}$ & 0.036 & $0.182^{* *}$ & $0.112^{*}$ & $0.148^{* *}$ & $0.314^{* *}$ & $0.344^{* *} c$ & $0.183^{* *}$ & $-0.524^{* *}$ & * 1.000 & & & & & & & & & & \\
\hline $\mathbf{K}$ & 0.076 & $0.175^{* *}$ & 0.083 & $0.289^{* *}$ & $0.338^{* *}$ & $0.519^{* *}$ & $0.646^{* *}$ & $0.469^{* *}$ & -0.007 & $0.458^{* *}$ & 1.000 & & & & & & & & & \\
\hline $\mathbf{L}$ & $-0.388^{* *}$ & $0.131^{* *}$ & 0.032 & -0.029 & -0.085 & $-0.149^{* * *}$ & $0.248^{* *} c$ & $0.721^{* *}$ & $0.129^{*}$ & -0.020 & $0.144^{* *}$ & 1.000 & & & & & & & & \\
\hline M & -0.053 & 0.058 & -0.072 & 0.043 & 0.089 & 0.035 & $0.156^{* *} c$ & $0.248^{* *}$ & $-0.111^{*}$ & $0.107^{*}$ & $0.126^{*}$ & $0.191^{* *}$ & 1.000 & & & & & & & \\
\hline $\mathbf{N}$ & $-0.283^{* *}$ & 0.017 & -0.054 & $-0.142^{* *}$ & ${ }^{*}-0.098$ & $-0.199^{* *}$ & 0.042 & $0.425^{* *}$ & -0.067 & 0.081 & 0.055 & $0.538^{* *} 0$ & $0.232^{* *}$ & 1.000 & & & & & & \\
\hline o & $-0.250^{* *}$ & 0.041 & -0.044 & -0.076 & -0.043 & 0.121 & $0.118^{*}$ & $0.441^{* *}$ & -0.095 & $0.135^{* *}$ & $0.107^{*}$ & $0.502^{* *} 0$ & $0.627^{* *}$ & $0.888^{* *}$ & 1.000 & & & & & \\
\hline $\mathbf{P}$ & -0.063 & $0.356^{* *}$ & $0.232^{* *}$ & $0.581^{* *}$ & $0.532^{* *}$ & $0.833^{* *}$ & $1.000^{* *} \mathrm{c}$ & $0.537^{* *}$ & -0.083 & $0.343^{* *}$ & $0.646^{* *}$ & $0.248^{* *} 0$ & $0.156^{* *}$ & 0.042 & $0.117^{*}$ & 1.000 & & & & \\
\hline $\mathbf{Q}$ & $0.186^{* *}$ & -0.017 & -0.004 & $0.119^{*}$ & $0.111^{*}$ & $0.146^{* *}$ & $0.281^{* *} c$ & $0.284^{* *}$ & -0.038 & 0.076 & $0.222^{* * *}$ & $0.226^{* *}$ & ${ }^{*}-0.025$ & 0.016 & $-0.009 c$ & $0.281^{* *}$ & 1.000 & & & \\
\hline $\mathbf{R}$ & $0.187^{* *}$ & 0.011 & -0.005 & $0.131^{* *}$ & $0.101^{*}$ & $0.129^{*}$ & $0.266^{* *} c$ & $0.280^{* *}$ & 0.004 & 0.060 & $0.223^{* *}$ & $0.243^{* *}$ & ${ }^{*}-0.039$ & 0.020 & -0.0110 & $0.266^{* *}$ & $0.973^{* *}$ & 1.000 & & \\
\hline S & $0.111^{*}$ & $0.104^{*}$ & -0.008 & 0.097 & 0.026 & 0.004 & $0.105^{*}$ & $0.163^{* *}$ & $0.124^{*}$ & -0.012 & $0.128^{*}$ & $0.214^{* *}$ & -0.061 & 0.050 & 0.011 & $0.105^{*}$ & $0.477^{* *}$ & $0.664^{* *}$ & 1.000 & \\
\hline $\mathbf{T}$ & $0.183^{* *}$ & 0.027 & -0.007 & $0.133^{* *}$ & 0.092 & $0.115^{*}$ & $0.250^{* *} c$ & $0.271^{* *}$ & 0.027 & 0.049 & $0.217^{* *}$ & $0.247^{* *}$ & ${ }^{*}-0.046$ & 0.022 & $0.011^{*}$ & $0.251^{* *}$ & $0.936^{* *} c$ & $0.992^{* *} 0$ & $.751^{* *}$ & 1.000 \\
\hline
\end{tabular}

${ }^{\dagger} \mathrm{A}=$ Sprout count 1 month after planting; $\mathrm{B}=$ Sprout count 2 months after planting; $\mathrm{C}=$ Tiller count 4 months after planting; $\mathrm{D}=$ Tiller count 5 months after planting; $\mathrm{E}=$ Millable stalk count 10 months after planting; $\mathrm{F}=$ Millable stalk count per hectare at harvest; $\mathrm{G}=$ Single cane weight $(\mathrm{kg}) ; \mathrm{H}=\mathrm{Number}$ of internodes; I = Internodes length (cm); J = Stalk height (cm); K = Stalk diameter (cm); L = Leaf length $(\mathrm{cm}) ; \mathrm{M}=$ Leaf width $(\mathrm{cm}) ; \mathrm{N}=$ Leaf area $\left(\mathrm{cm}^{2}\right) ; \mathrm{O}=\mathrm{Cane}$ yield (qt/ha); P = Laboratory brix\%; Q = Pol\%; R = Purity\%; S = Sugar \%; T = Sugar yield (qt/ha); ** and * = highly significant at P $<0.01$ and $\mathrm{P}=0.05$ respectively.

On the other hand [46] reported significant genetic correlation of leaf area with stalk height, stalk diameter and internodes length.

Sugar quality parameters showed highly significant strong positive genetic correlations with each other and with sugar yield revealing that any of these juice quality traits could be considered for selection leading to the simultaneous improvement in the remaining quality traits and sugar yield [48] [51].

Moderate to high highly significant positive phenotypic correlations with most of the traits were observed for number of millable cane and cane yield. The phenotypic correlations of sugar quality parameters and sugar yield with number of millable cane were positive and highly significant. Highly significant negative correlations with number of millable cane were observed for internode length, leaf length and leaf area and non significant positive correlation with cane yield. It was demonstrated by [11] that phenotypic correlations between cane yield and single cane weight, number of internodes, stalk diameter, stalk height and number of millable canes were positive and significant. They further indicated that number of millable canes was negatively correlated with all other yield components.

Phenotypic significant and positive association of cane yield with single cane weight, number of internodes, stalk height and diameter, leaf length and width, leaf area, brix\% and sugar yield was recorded. Association with pol\% and purity percent was negative and non significant while positive and non significant with millable cane number and sugar\%. Negative correlation of pol \% with cane yield was also found by [49] in their study. In 
conformity with the present study significant positive phenotypic correlation of cane yield with number of internodes, stalk height and diameter and millable cane number [11] and with sugar yield [52] was reported.

Sugar yield was observed to have positive significant phenotypic correlation with sprout count 1 month after planting, tiller count 5 months after planting, number of millable cane, single cane weight, number of internodes, stalk diameter, leaf length, cane yield, brix\%, pol\%, purity\% and sugar\%. Sugar yield mainly depends on number of tillers, cane weight, pol\%, sugar\% and purity\% [49]. The negative correlation of pol\% with cane yield and positive correlation with sugar yield is one of the major constraints in the improvement of sugarcane [49]. Reference [52] reported strong positive phenotypic correlation of sugar yield with number of millable cane, single cane weight, stalk height, cane yield and non significant positive association with stalk diameter.

Single cane weight, number of internodes, stalk diameter and leaf length also showed highly significant positive phenotypic correlations with most of the traits including sugar quality parameters, cane and sugar yield. This is corroborated by the findings of [11] who reported significant positive correlation of single cane weight with number of internodes, stalk diameter, stalk height and cane yield. It is amazing to notice in the current study that single cane weight, number of internodes, stalk diameter and leaf length had significant positive association with both cane and sugar yield indicating the significance of these traits in improving both cane and sugar yields.

Stalk height demonstrated highly significant positive phenotypic correlations with millable cane number, cane yield, brix percent and most of the yield components but the association with sugar yield was non-significant.

Sugar quality parameters showed highly significant moderate to high positive phenotypic correlations with each other and with sugar yield.

In general, genotypic correlation coefficients were higher than their corresponding phenotypic correlation coefficients indicating a fairly strong inherent relationship among the traits [11].

The lower estimates of phenotypic correlation indicated that the relationships were affected by environment at phenotypic level [49]. Such environmental influence in reducing the correlation coefficients in rice was also reported by [53]. Correlations among phenotypic traits may reflect biological processes that are of considerable evolutionary interest and can be the result of genetic, functional and physiological or developmental nature [54] [55].

In this study, most of the important yield components had positive genetic and phenotypic association with cane yield (Table 3 and Table 4). The strong genetic correlation of single cane weight, stalk diameter and number of internodes with other agronomic traits suggests that selection of these traits could simultaneously improve the other traits. On the other hand, though nonsignificant, the negative genetic association of number of millable cane with internodes length, leaf length, leaf area and sugar percent indicates that improvement in the former could result in decrease in the latter traits. These results together with the information obtained on heritability and genetic advance indicated that single cane weight, stalk diameter and millable cane number are the key component characters of cane yield. Sugarcane genotypes with high cane yield have been selected on the basis of stalk number and single cane weight [56].

\section{Conclusions}

This study revealed that cane yield was associated with its various components, sugar quality traits and sugar yield genetically and phenotypically in various magnitudes. Further, the study has indicated the magnitude of the correlations among cane yield traits, their heritability, expected genetic advance and genotype $\times$ environment interactions that could be encountered within the sugarcane breeding programme and demonstrated differential responses of different sugarcane clones to various environmental conditions.

The results suggest that evaluation of sugarcane clones for cane and sugar yield in many locations should identify superior clones. This testing approach coupled with a selection strategy based on single cane weight, stalk diameter and number of millable canes per unit area might result in significant genetic improvement in cane and sugar yield. This study also reveals that higher number of tillers, number of millable cane, single cane weight, number of internodes, stalk diameter, leaf length endowed with better pol\%, purity\% and sugar\% are the important characters which should be considered while selection to be made for higher sugar yield in sugarcane genotypes.

\section{Acknowledgements}

The authors are grateful to the financial grant of the Sugar Corporation of Ethiopia. Many thanks are forwarded to Ethiopian Institute of Biodiversity for its technical advice during collection of the local sugarcane genotypes. The 
staff and laboratory technicians at Wonji and Metehara, Sugar Corporation, Research and Training are duly acknowledged for their supports.

\section{References}

[1] Ethiopian Sugar Corporation (ESC) (2011) Ethiopian Sugar Corporation Strategic Plan.

[2] Esayas, T. (2014) Exploration and Collection, Characterization, Genetic Diversity Analysis and Association of Traits for Yield and Yield Components of Sugarcane (Saccharum spp.) in Ethiopia. PhD Dissertation, Haramaya University, Haramaya.

[3] Bakhsh, A., Arshad, M. and Haqqan, A.M. (2006) Effect of Genotype $\times$ Environment Interaction on Relationship between Grain Yield and Its Components in Chickpea (Cicer arietinum L.). Pakistan Journal of Botany, 38, 683-690.

[4] Da Silva, F.F., Pereira, M.G., Ramos, H.C.C., Damasceno Jr., P.C., Pereira, N.S. and Ide, C.D. (2007) Genotypic Correlations of Morpho-Agronomic Traits in Papayas and Implications for Genetic Breeding. Crop Breeding and Applied Biotechnology, 7, 345-352. http://dx.doi.org/10.12702/1984-7033.v07n04a03

[5] Jackson, P. (1994) Genetic Relationships between Attributes in Sugarcane Clones Closely Related to Saccharum spontaneum. Euphytica, 79, 101-108. http://dx.doi.org/10.1007/BF00023581

[6] Tyagi, S.D. and Khan, M.H. (2010) Studies on Genetic Variability and Interrelationship among the Different Traits in Microsperma Lentil (Lens culinaris Medik). Journal of Agricultural Biotechnology and Sustainable Development, 2, 15-20.

[7] De Sousa-Vierra, O. and Milligan, S.B. (2005) Interrelationships of Cane Yield Components and Their Utility in Sugarcane Family Selection: Path Coefficient Analysis. Interciencia, 30, 93-96.

[8] Milligan, S.B., Gravois, K.A., Bischoff, K.P. and Martin, F.A. (1990) Crop Effects on Broad-Sense Heritability and Genetic Variances of Sugarcane Yield Components. Crop Science, 30, 344-349. http://dx.doi.org/10.2135/cropsci1990.0011183X003000020020x

[9] Gravois, K.A., Milligan, S.B. and Martin, F.A. (1991) Additive Genetic Effects for Sugarcane Yield Components and Implications for Hybridization. Tropical Agriculture (Trinidad), 68, 376-380.

[10] Tyagi, A.P. and Lal, P. (2007) Correlation and Path Coefficient Analysis in Sugarcane. South Pacific Journal of Natural Science, 25, 1-9. http://dx.doi.org/10.1071/SP07001

[11] Jamoza, J.E., Owuoche, J., Kiplagat, O. and Opile, W. (2014) Broad-Sense Heritability Estimation and Correlation among Sugarcane (Saccharum spp. Hybrids) Yield and Some Agronomic Traits in Western Kenya. International Journal of Agricultural Policy and Research, 2, 016-025.

[12] Pandey, R.A. (1989) Variability Study in the Hybrid Progenies of Sugarcane (Saccharum Complex). Bharatiya Sugar, 49-51.

[13] Chavanne, E.R. and Mariotti, J.A. (1989) The Efficiency of Clonal Selection across Environments in Sugarcane. Proceeding of International Society of Sugar Cane Technologists, 209, 917-924.

[14] Pires, C.E.L.S. and da Costa, E.F.S. (1980) Association between Some Characters of Sugarcane (Saccharum spp.) Grown in Four Localities in the Northeast of Brazil. Proceeding of International Society of Sugar Cane Technologists, 17, 1365-1372.

[15] Ram, B. and Hemaprabha, G. (1992) Genetic Variability in Interspecific Progenies in Sugarcane (Saccharum spp.). Indian Journal of Genetics, 52, 192-198.

[16] Chaudhary, R.R. (2001) Genetic Variability and Heritability in Sugarcane. Nepal Agricultural Research Journal, 4, 5659.

[17] Kimbeng, C.A., Rattey, A.R. and Hetherington, M. (2002) Interpretation and Implications of Genotype by Environment Interactions in Advanced Stage Sugarcane Selection Trials in Central Queensland. Australian Journal of Agricultural Research, 53, 1035-1045. http://dx.doi.org/10.1071/AR01190

[18] Parfitt, R.C. (2000) Genotype $\times$ Environment Interaction among Secondary Variety Trials in the Northern Region of the South African Sugar Industry. Proceeding of South Africa Sugar Technology Association, 74, 245-258.

[19] Glaz, B. and Kang, M.S. (2008) Location Contributions Determined via GGE Biplot Analysis of Multi Environment Sugarcane Genotype-performance Trials. Crop Science, 48, 941-950. http://dx.doi.org/10.2135/cropsci2007.06.0315

[20] Falconer, D.S. and Mackay, T.F.C. (1996) Introduction to Quantitative Genetics. 4th Edition, Addison Wesley Longman, Harlow.

[21] Holland, J.B., Nyquist, W.E. and Cervantes-Martinez, C.T. (2003) Estimating and Interpreting Heritability for Plant Breeding: An Update. Plant Breeding Reviews, 22, 11-112.

[22] Gravois, K.A. and Milligan, S.B. (1992) Genetic Relationships between Fibre and Sugarcane Yield Components. Crop 
Science, 32, 62-67. http://dx.doi.org/10.2135/cropsci1992.0011183X003200010014x

[23] Falconer, D.S. (1989) Introduction to Quantitative Genetics. 3rd Edition, Longman, New York.

[24] Holland, J.B. (2006) Estimating Genotypic Correlations and Their Standard Errors Using Multivariate Restricted Maximum Likelihood Estimation with SAS Proc MIXED. Crop Science, 46, 642-654. http://dx.doi.org/10.2135/cropsci2005.0191

[25] Cardinal, A.J. and Burton, J.W. (2007) Correlations between Palmitate Content and Agronomic Traits in Soybean Populations Segregating for the fap1, fap $n$, and fan Alleles. Crop Science, 47, 1804-1812. http://dx.doi.org/10.2135/cropsci2006.09.0577

[26] Punia, M.S. (1982) Studies on Variability, Heritability and Genetic Advance of Some Quality Attributes in Sugarcane. Indian Sugar, 31, 911-914.

[27] Khan, I.A., Khatari, A., Siddiqui, M.A., Nizamani, G.S. and Raza, S. (2004) Performance of Promising Sugarcane Clones for Yield and Quality in Different Ecological Zones of Sindhi. Pakistan Journal of Botany, 36, 83-92.

[28] Chang, Y.S. (1996) Estimating Heritability of and Correlations among Brix, Purity and Sugar Content in Sugarcane Using Balanced Multiple Location and Year Data. Report of Taiwan Sugar Research Institute, 151, 1-10.

[29] Butterfield, M.K. and Nuss, K.J. (2002) Prospects for New Varieties in the Medium to Long Term: The Effects of Current and Future Breeding Strategy on Variety Characteristics.

[30] Balasundaram, N. and Bhagyalakshmi, B. (1978) Variability, Heritability and Association among Yield and Yield Components of Sugarcane. Indian Journal of Agricultural Science, 48, 291-295.

[31] Nair, N.V., Somarajan, K.G. and Baasundaram, N. (1980) Genetic Variability, Heritability and Genetic Advance in Saccharum officinarum. International Sugarcane Journal, 82, 275-276.

[32] Singh, R.K. and Singh, G.P. (1999) Effect of Early Evaluation of Genotypes on Genetic Variability, Repeatability and Predictability in Plant and Ratoon Crops of Sugarcane. Sugar Technology, 1, 128-131. http://dx.doi.org/10.1007/BF02945186

[33] Singh, R. and Sangwan, R.S. (1980) Studies on Genetic Variability for Stalk Characters in Sugarcane. Indian Sugar, 30, 409-412.

[34] Singh, R.K. and Singh, S. (1994) Early Evaluation of Crosses for Varietal Improvement in Sugarcane. Sugar Cane, 3, $17-21$.

[35] Singh, R.K. and Singh, G.P. (1998) Effect of Sampling Time on Efficacy of Selection for Quality Traits in Sugarcane. Sugar Cane, 2, 12-18.

[36] Singh, R.K., Singh, D.N., Singh, S.K. and Singh, H.N. (1994) Genetic Variability and Correlation Studies in Foreign Commercial Hybrids of Sugarcane. Agricultural Science Digest (Karnal), 14, 103-107.

[37] Singh, B.D. (1993) Plant Breeding. 5th Edition, Kalyani Publishers, Ludhiana, 102-104.

[38] Wunna, H., Jogloy, S., Toomsan, B., Sanitcon, J. and Patanothai, A. (2009) Inheritance of Traits Related to Biological Nitrogen Fixation and Genotypic Correlation of Traits Related to Nitrogen Fixation, Yield and Drought Tolerance in Peanut (Arachis hypogea L.) under Early Drought. Asian Journal of Plant Sciences, 8, 265-275. http://dx.doi.org/10.3923/ajps.2009.265.275

[39] Vidya, K.L., Oommen, S.K. and Vijayaraghava, K. (2002) Genetic Variability and Heritability of Yield and Related Characters in Yard-Long Bean. Journal of Tropical Agriculture, 40, 11-13.

[40] Shoba, D., Manivannan, N. and Vindhiyavarman, P. (2009) Studies on Variability, Heritability and Genetic Advance in Groundnut (Arachis hypogea L.). Electronic Journal of Plant Breeding, 1, 74-77.

[41] Johnson, H.W., Robinson, H.F. and Comstock, R.E. (1955) Estimates of Genetic and Environmental Variability in Soybean. Agronomy Journal, 47, 314-318. http://dx.doi.org/10.2134/agronj1955.00021962004700070009x

[42] Sahi, B.K., Shah, S.S. and Patel, K.A. (1977) Variability in Early Varieties of Sugarcane in Plant and Ratoon Crops. Indian Journal of Genetics and. Plant Breeding, 37, 496-500.

[43] Tyagi, S.D. and Singh, D.N. (1998) Studies on Genetic Variability for Stalk Characters in Sugarcane. Indian Sugar, 48, 259-262.

[44] Kamat, D.N. and Singh, J.R.P. (2001) Variability in Sugarcane under Rain Fed Conditions. Sugar Technology, 3, 65-67. http://dx.doi.org/10.1007/BF02945535

[45] Bakshi, R. (2005) Estimation of Genetic Parameters in Different Environments and Their Implications in Sugarcane Breeding. Indian Journal of Genetics, 65, 219-220.

[46] Khan, F.A., Iqbal, M.Y. and Sultan, M. (2007) Morphogenetic Behaviour of Some Agronomic Traits of Sugarcane (Saccharum officinarum L.). Pakistan Journal of Agricultural Science, 44, 600-603.

[47] Khan, I.A., Dahot, M.U. and Abdullah, K. (2007) Study of Genetic Variability in Sugarcane Induced through Mutation 
Breeding. Pakistan Journal of Botany, 39, 1489-1501.

[48] Thippeswamy, S., Kajjidoni, S.T., Salimath, P.M. and Goud, J.V. (2003) Correlation and Path Analysis for Cane Yield, Juice Quality and Their Component Traits in Sugarcane. Sugar Technology, 5, 65-72. http://dx.doi.org/10.1007/BF02943767

[49] Khan, I.A., Bibi, S., Yasmin, S., Khatri, A., Seema, N. and Abro, S.A. (2012) Correlation Studies of Agronomic Traits for Higher Sugar Yield in Sugarcane. Pakistan Journal of Botany, 44, 969-971.

[50] Verma, P.S., Pal, S., Karma, N.K. and Pal, S. (1999) Genetic Variability and Correlation Studies in Sugarcane. Indian Sugar, 49, 125-128.

[51] Sreekumar, K.J., Kuriakose, M., Thomas, M., Alexander, D. and Santhakumari, S. (1994) Variability, Heritability and Correlation on Studies on the Yield and Quality Characters of Sugarcane. Indian Sugar, 44, 243-249.

[52] Tyagi, V.K., Satish, S. and Bhardwaj, S.B. (2012) Pattern of Association among Cane Yield, Sugar Yield and Their Components in Sugarcane (Saccharum Officinarum L.). Journal of Agricultural Research, 50, 29.

[53] Chaudhary, P.K. and Singh, R.P. (1994) Genetic Variability, Correlation and Path Analysis of Yield Components of Rice. Madras Agriculture Journal, 81, 468-470.

[54] Soomro, A.F., Junejo, S., Ahmed, A. and Aslam, M. (2006) Evaluation of Different Promising Sugarcane Varieties for Some Quantitative and Qualitative Attributes under Thatta (Pakistan) Conditions. International Journal of Agriculture and Biology, 8, 195-197.

[55] Ulloa, M. (2006) Heritability and Correlations of Agronomic and Fibre Traits in an Okra-Leaf Upland Cotton Population. Crop Science, 46, 1508-1514. http://dx.doi.org/10.2135/cropsci2005.08-0271

[56] Singh, P., Archana, S. and Singh, B. (2007) Studies on Genetic Relationships in Plant and Ratoon Crops of Sugarcane. Proceeding of Annual Convention Sugar Technologists' Association of India, 68, 36-45. 
Appendixes

Appendix 1. Passport data of local sugarcane genotypes collected during 2010/11.

\begin{tabular}{|c|c|c|c|c|c|c|c|}
\hline $\begin{array}{l}\text { Code } \\
\text { No. }\end{array}$ & Common Name & $\begin{array}{l}\text { Date } \\
\text { Collected }\end{array}$ & Collector & $\begin{array}{l}\text { Collector's } \\
\text { Number }\end{array}$ & $\begin{array}{c}\text { Region/Zone/Wereda/Kebele/ } \\
\text { Village }\end{array}$ & Lat/Long & $\begin{array}{l}\text { Altitude } \\
\text { (m) }\end{array}$ \\
\hline 1 & Nach Shenkora & $10 / 08 / 2010$ & Esayas Tena & 3 & $\begin{array}{c}\text { SNNP/Gurage/Absege/Nachakulit/ } \\
\text { Misreta }\end{array}$ & $\begin{array}{l}08^{\circ} 20.989^{\prime} / \\
37^{\circ} 33.954^{\prime}\end{array}$ & 1521 \\
\hline 2 & $\begin{array}{c}\text { Bicha } \\
\text { Shenkora/Weliso }\end{array}$ & $10 / 08 / 2010$ & Esayas Tena & 4 & $\begin{array}{c}\text { SNNP/Gurage/Absege/Nachakulit/ } \\
\text { Misreta }\end{array}$ & $\begin{array}{l}08^{\circ} 20.989^{\prime} / \\
37^{\circ} 33.954^{\prime}\end{array}$ & 1521 \\
\hline 3 & Kay Shenkora & $10 / 08 / 2010$ & Esayas Tena & 5 & $\begin{array}{c}\text { SNNP/Gurage/Absege/Nachakulit/ } \\
\text { Misreta }\end{array}$ & $\begin{array}{l}08^{\circ} 20.989^{\prime} / \\
37^{\circ} 33.954^{\prime}\end{array}$ & 1521 \\
\hline 4 & $\begin{array}{l}\text { Andegna Dereja } \\
\text { Canada Shenkora }\end{array}$ & $12 / 08 / 2010$ & Esayas Tena & 7 & SNNP/Silttie/Silttie/Balokeriso & $\begin{array}{l}07^{\circ} 58.907^{\prime} / \\
038^{\circ} 22.558\end{array}$ & 1824 \\
\hline 5 & Ye abesha shenkora & $21 / 08 / 2010$ & Esayas Tena & 19 & $\begin{array}{c}\text { SNNP/Gamogofa/Bonke/Geresse } \\
\text { Zala/ }\end{array}$ & $\begin{array}{l}05^{\circ} 54.307^{\prime} / \\
037^{\circ} 18.54^{\prime}\end{array}$ & 2258 \\
\hline 6 & Bicha Shenkora & $20 / 08 / 2010$ & Esayas Tena & 17 & $\begin{array}{c}\text { SNNP/Gamogofa/Bonke/Geresse } \\
\text { Zala/Tsophi }\end{array}$ & $\begin{array}{l}05^{\circ} 54.476^{\prime} / \\
037^{\circ} 18.38^{\prime}\end{array}$ & 2133 \\
\hline 7 & Kay Sidancho & 27/08/2010 & Esayas Tena & 31 & $\begin{array}{c}\text { SNNP/Sidama/Borecha/Yloubancho/ } \\
\text { Agoyicho }\end{array}$ & $\begin{array}{l}06^{\circ} 56.060^{\prime} / \\
038^{\circ} 22.793^{\prime}\end{array}$ & 2042 \\
\hline 8 & Kay Shenkora & $20 / 08 / 2010$ & Esayas Tena & 18 & $\begin{array}{c}\text { SNNP/Gamogofa/Bonke/Geresse } \\
\text { Zala/Tsophi }\end{array}$ & $\begin{array}{l}05^{\circ} 54.476^{\prime} / \\
037^{\circ} 18.38^{\prime}\end{array}$ & 2133 \\
\hline 9 & $\begin{array}{c}\text { Kay } \\
\text { Shenkora/Huletegna } \\
\text { dereja canada } \\
\text { Shenkora }\end{array}$ & $12 / 08 / 2010$ & Esayas Tena & 8 & SNNP/Silttie/Silttie/Balokeriso & $\begin{array}{l}07^{\circ} 58.907^{\prime} / \\
038^{\circ} 22.558^{\prime}\end{array}$ & 1824 \\
\hline 10 & Burabure Shenkora & $10 / 08 / 2010$ & Esayas Tena & 6 & $\begin{array}{c}\text { SNNP/Gurage/Absege/Nachakulit/ } \\
\text { Misreta }\end{array}$ & $\begin{array}{l}08^{\circ} 20.989^{\prime} / \\
37^{\circ} 33.954^{\prime}\end{array}$ & 1521 \\
\hline 11 & $\begin{array}{l}\text { Yegurage Shenkora/ } \\
\text { Kay Shenkora }\end{array}$ & $10 / 08 / 2010$ & Esayas Tena & 1 & SNNP/Gurage/Absege/Jejeba/Jejeba & $\begin{array}{l}08^{\circ} 16.298^{\prime} / \\
037^{\circ} 43.384^{\prime}\end{array}$ & 1808 \\
\hline 12 & Yejima Shenkora & $10 / 08 / 2010$ & Esayas Tena & 2 & SNNP/Gurage/Absege/Jejeba/Jejeba & $\begin{array}{l}08^{\circ} 16.298^{\prime} / \\
037^{\circ} 43.384^{\prime}\end{array}$ & 1808 \\
\hline 13 & Kay Shenkora & $12 / 08 / 2010$ & Esayas Tena & 9 & SNNP/Silttie/Werabe/02 Kebele & $\begin{array}{l}07^{\circ} 49.933^{\prime} / \\
038^{\circ} 10.793^{\prime}\end{array}$ & 2101 \\
\hline 14 & $\begin{array}{l}\text { Ye Abesha shenkora } \\
\text { (Nach Shenkora) }\end{array}$ & $17 / 08 / 2010$ & Esayas Tena & 13 & $\begin{array}{l}\text { SNNP/South Omo/Debub } \\
\text { Ari/Mester/Jagame }\end{array}$ & $\begin{array}{l}05^{\circ} 59.202 / \\
036^{\circ} 35.037^{\prime}\end{array}$ & 1705 \\
\hline 15 & Wolesh & $16 / 08 / 2010$ & Esayas Tena & 12 & $\begin{array}{l}\text { SNNP/South Omo/Debub } \\
\text { Ari/Bazet/Ekzek }\end{array}$ & $\begin{array}{l}05^{\circ} 47.213^{\prime} / \\
036^{\circ} 34.900^{\prime}\end{array}$ & 1436 \\
\hline 16 & Wolesh/Tinkish & $16 / 08 / 2010$ & Esayas Tena & 11 & $\begin{array}{l}\text { SNNP/South Omo/Debub } \\
\text { Ari/Bazet/Ekzek }\end{array}$ & $\begin{array}{l}05^{\circ} 47.213^{\prime} / \\
036^{\circ} 34.900^{\prime}\end{array}$ & 1436 \\
\hline 18 & $\begin{array}{l}\text { Nach (Arenguade) } \\
\text { Ageda }\end{array}$ & $19 / 08 / 2010$ & Esayas Tena & 16 & $\begin{array}{l}\text { SNNP/Konso Special Wereda/ } \\
\text { Gaserge Kebele }\end{array}$ & $\begin{array}{l}05^{\circ} 96.038^{\prime} / \\
037^{\circ} 21.194^{\prime}\end{array}$ & 1727 \\
\hline 19 & Burabure Shenkora & $18 / 08 / 2010$ & Esayas Tena & 15 & $\begin{array}{l}\text { SNNP/Konso Special Wereda/Busso } \\
\text { Kebele }\end{array}$ & $\begin{array}{l}05^{\circ} 18.495^{\prime} / \\
037^{\circ} 25.28^{\prime}\end{array}$ & 1357 \\
\hline 20 & Wonji & $16 / 08 / 2010$ & Esayas Tena & 10 & $\begin{array}{l}\text { SNNP/South Omo/Debub Ari/ } \\
\text { Bazet/Ekzek }\end{array}$ & $\begin{array}{l}05^{\circ} 47.213^{\prime} / \\
036^{\circ} 34.900^{\prime}\end{array}$ & 1436 \\
\hline 21 & Wolshi & $17 / 08 / 2010$ & Esayas Tena & 14 & SNNP/South Omo/Debub Ari/Metser & $\begin{array}{l}\text { Collected from } \\
\text { market }\end{array}$ & \\
\hline 22 & American & $27 / 08 / 2010$ & Esayas Tena & 32 & $\begin{array}{c}\text { SNNP/Sidama/Borecha/Yloubancho/ } \\
\text { Agoyicho }\end{array}$ & $\begin{array}{l}06^{\circ} 55.908^{\prime} / \\
038^{\circ} 22.793^{\prime}\end{array}$ & 2059 \\
\hline 23 & Jambo & $27 / 08 / 2010$ & Esayas Tena & 29 & $\begin{array}{c}\text { SNNP/Sidama/Borecha/Yloubancho/ } \\
\text { Agoyicho }\end{array}$ & $\begin{array}{l}06^{\circ} 56.060^{\prime} / \\
038^{\circ} 22.793^{\prime}\end{array}$ & 2042 \\
\hline
\end{tabular}




\section{Continued}

\begin{tabular}{|c|c|c|c|c|c|c|c|}
\hline 24 & Nach Sidancho & $27 / 08 / 2010$ & Esayas Tena & 30 & $\begin{array}{c}\text { SNNP/Sidama/Borecha/Yloubancho/ } \\
\text { Agoyicho }\end{array}$ & $\begin{array}{l}06^{\circ} 56.060^{\prime} / \\
038^{\circ} 22.793^{\prime}\end{array}$ & 2042 \\
\hline 25 & Azaro, Kollo & $25 / 08 / 2010$ & Esayas Tena & 21 & $\begin{array}{l}\text { SNNP/Amaro special Wereda/Jijola } \\
\text { kebele/Kore village/Cheffa District }\end{array}$ & $\begin{array}{l}05^{\circ} 40.446^{\prime} / \\
037^{\circ} 55.669^{\prime}\end{array}$ & 1410 \\
\hline 26 & Wonji & 25/08/2010 & Esayas Tena & 23 & $\begin{array}{l}\text { SNNP/Amaro special Wereda/Jijola } \\
\text { kebele/Kore village/Cheffa District }\end{array}$ & $\begin{array}{l}05^{\circ} 40.446^{\prime} / \\
037^{\circ} 55.669^{\prime}\end{array}$ & 1410 \\
\hline 27 & Kembata & 26/08/2010 & Esayas Tena & 25 & SNNP/Gedeo/Wenago/Deko & $\begin{array}{l}06^{\circ} 16.889^{\prime} / \\
038^{\circ} 12.919^{\prime}\end{array}$ & 1914 \\
\hline 28 & Nach Shenkora & $25 / 08 / 2010$ & Esayas Tena & 24 & $\begin{array}{l}\text { SNNP/Amaro special Wereda/Jijola } \\
\text { kebele/Kore village/Cheffa District }\end{array}$ & $\begin{array}{l}05^{\circ} 40.446^{\prime} / \\
037^{\circ} 55.669^{\prime}\end{array}$ & 1410 \\
\hline 29 & Andegna dereja Wonji & 01/09/2010 & Esayas Tena & 44 & SNNP/Wolayta/Damotgale/Gacheno & $\begin{array}{l}07^{\circ} 02.280^{\prime} / \\
037^{\circ} 55.072^{\prime}\end{array}$ & 1882 \\
\hline 30 & $\begin{array}{l}\text { Sidama/Yegamo } \\
\text { Shenkora }\end{array}$ & $25 / 08 / 2010$ & Esayas Tena & 22 & $\begin{array}{l}\text { SNNP/Amaro special Wereda/Jijola } \\
\text { kebele/Kore village/Cheffa District }\end{array}$ & $\begin{array}{l}05^{\circ} 40.446^{\prime} / \\
037^{\circ} 55.669^{\prime}\end{array}$ & 1410 \\
\hline 31 & $\begin{array}{l}\text { Huletegna dereja } \\
\text { Jambo key }\end{array}$ & 26/08/2010 & Esayas Tena & 27 & $\begin{array}{c}\text { Oromia/West Arsi/Wondo/Shesha } \\
\text { Kebele }\end{array}$ & $\begin{array}{l}07^{\circ} 05.662^{\prime} / \\
038^{\circ} 36.203^{\prime}\end{array}$ & 1705 \\
\hline 32 & $\begin{array}{c}\text { Andegna dereja Jambo } \\
\text { key }\end{array}$ & 26/08/2010 & Esayas Tena & 26 & $\begin{array}{c}\text { Oromia/West Arsi/Wondo/Shesha } \\
\text { Kebele }\end{array}$ & $\begin{array}{l}07^{\circ} 05.662^{\prime} / \\
038^{\circ} 36.203^{\prime}\end{array}$ & 1705 \\
\hline 33 & $\begin{array}{l}\text { Sostegna dereja Jambo } \\
\text { key/ Metfo Shenkora }\end{array}$ & 26/08/2010 & Esayas Tena & 28 & $\begin{array}{c}\text { Oromia/West Arsi/Wondo/Shesha } \\
\text { Kebele }\end{array}$ & $\begin{array}{l}07^{\circ} 05.662^{\prime} / \\
038^{\circ} 36.203^{\prime}\end{array}$ & 1705 \\
\hline 34 & Moliso & $30 / 08 / 2010$ & Esayas Tena & 35 & $\begin{array}{l}\text { SNNP/Konta Special Wereda/Cheka } \\
\text { Bocha kebele/Bocha Village }\end{array}$ & $\begin{array}{l}07^{\circ} 05.953^{\prime} / \\
036^{\circ} 39.495^{\prime}\end{array}$ & 1996 \\
\hline 35 & Nach Shenkora & $30 / 08 / 2010$ & Esayas Tena & 37 & $\begin{array}{l}\text { SNNP/Konta Special Wereda/Cheka } \\
\text { Bocha Kebele }\end{array}$ & $\begin{array}{l}07^{\circ} 06.244^{\prime} / \\
036^{\circ} 40.164^{\prime}\end{array}$ & 2105 \\
\hline 36 & Tazma/Burabure & $30 / 08 / 2010$ & Esayas Tena & 34 & $\begin{array}{l}\text { SNNP/Konta Special Wereda/Cheka } \\
\text { Bocha kebele/Bocha Village }\end{array}$ & $\begin{array}{l}07^{\circ} 05.953^{\prime} / \\
036^{\circ} 39.495^{\prime}\end{array}$ & 1996 \\
\hline 37 & Wolayta & 01/09/2010 & Esayas Tena & 43 & SNNP/Wolayta/Damotgale/Gacheno & $\begin{array}{l}07^{\circ} 02.280^{\prime} / \\
037^{\circ} 55.072^{\prime}\end{array}$ & 1882 \\
\hline 38 & Kay Shenkora & $31 / 08 / 2010$ & Esayas Tena & 38 & $\begin{array}{c}\text { SNNP/Dawro/Mareka/MedaKuli/ } \\
\text { Wushay }\end{array}$ & $\begin{array}{l}07^{\circ} 00.612^{\prime} / \\
037^{\circ} 12.285^{\prime}\end{array}$ & 2163 \\
\hline 39 & Key Shenkora & $30 / 08 / 2010$ & Esayas Tena & 33 & $\begin{array}{l}\text { SNNP/Konta Special Wereda/Cheka } \\
\text { Bocha kebele/Bocha Village }\end{array}$ & $\begin{array}{l}07^{\circ} 05.953^{\prime} / \\
036^{\circ} 39.495^{\prime}\end{array}$ & 1996 \\
\hline 40 & Atena Moris & 02/09/2010 & Esayas Tena & 45 & $\begin{array}{c}\text { SSNP/Kembata Tembaro/Kacha } \\
\text { Bira/Mesena }\end{array}$ & $\begin{array}{l}07^{\circ} 10.944^{\prime} / \\
037^{\circ} 46.746^{\prime}\end{array}$ & 1838 \\
\hline 41 & Dolche & 01/09/2010 & Esayas Tena & 41 & SNNP/Wolayta/Damotgale/Gacheno & $\begin{array}{l}07^{\circ} 02.280^{\prime} / \\
037^{\circ} 55.072^{\prime}\end{array}$ & 1882 \\
\hline 42 & Kay Ageda Shenkora & 03/09/2010 & Esayas Tena & 51 & $\begin{array}{l}\text { SNNP/Halaba kulito Special } \\
\text { Wereda/Alemtena }\end{array}$ & $\begin{array}{l}07^{\circ} 22.433^{\prime} / \\
038^{\circ} 06.433^{\prime}\end{array}$ & 1797 \\
\hline 43 & Moris & 03/09/2010 & Esayas Tena & 52 & $\begin{array}{l}\text { SNNP/Halaba kulito Special } \\
\text { Wereda/Alemtena }\end{array}$ & $\begin{array}{l}07^{\circ} 22.433^{\prime} / \\
038^{\circ} 06.433^{\prime}\end{array}$ & 1797 \\
\hline 44 & Bolfe & 02/09/2010 & Esayas Tena & 47 & $\begin{array}{c}\text { SSNP/Kembata Tembaro/Kacha } \\
\text { Bira/Mesena }\end{array}$ & $\begin{array}{l}07^{\circ} 10.944^{\prime} / \\
037^{\circ} 46.746^{\prime}\end{array}$ & 1838 \\
\hline 45 & Abesha & 02/09/2010 & Esayas Tena & 46 & $\begin{array}{c}\text { SSNP/Kembata Tembaro/Kacha } \\
\text { Bira/Mesena }\end{array}$ & $\begin{array}{l}07^{\circ} 10.944^{\prime} / \\
037^{\circ} 46.746^{\prime}\end{array}$ & 1838 \\
\hline 46 & Wotete & 02/09/2010 & Esayas Tena & 48 & $\begin{array}{c}\text { SSNP/Kembata Tembaro/Kacha } \\
\text { Bira/Mesena }\end{array}$ & $\begin{array}{l}07^{\circ} 10.944^{\prime} / \\
037^{\circ} 46.746^{\prime}\end{array}$ & 1838 \\
\hline 47 & Tazma/Burabure & $31 / 08 / 2010$ & Esayas Tena & 39 & $\begin{array}{l}\text { SNNP/Dawro/Mareka/MedaKuli/ } \\
\text { Gendomeda }\end{array}$ & $\begin{array}{l}06^{\circ} 58.977^{\prime} / \\
037^{\circ} 11.493^{\prime}\end{array}$ & 1803 \\
\hline
\end{tabular}




\section{Continued}

\begin{tabular}{|c|c|c|c|c|c|c|c|}
\hline 48 & Betam nach Shenkora & $30 / 08 / 2010$ & Esayas Tena & 36 & $\begin{array}{l}\text { SNNP/Konta Special Wereda/Cheka } \\
\text { Bocha Kebele }\end{array}$ & $\begin{array}{l}07^{\circ} 06.244^{\prime} / \\
036^{\circ} 40.164^{\prime}\end{array}$ & 2105 \\
\hline 49 & Wonji-1 & 02/09/2010 & Esayas Tena & 49 & $\begin{array}{c}\text { SSNP/Kembata Tembaro/Kacha } \\
\text { Bira/Wonko }\end{array}$ & $\begin{array}{l}07^{\circ} 12.316^{\prime} / \\
037^{\circ} 50.843^{\prime}\end{array}$ & 1952 \\
\hline 50 & Bishoftu & 02/09/2010 & Esayas Tena & 50 & $\begin{array}{c}\text { SSNP/Kembata Tembaro/Kacha } \\
\text { Bira/Wonko }\end{array}$ & $\begin{array}{l}07^{\circ} 12.316^{\prime} / \\
037^{\circ} 50.843^{\prime}\end{array}$ & 1952 \\
\hline 51 & Wotet & 01/09/2010 & Esayas Tena & 42 & SNNP/Wolayta/Damotgale/Gacheno & $\begin{array}{l}07^{\circ} 02.280^{\prime} / \\
037^{\circ} 55.072^{\prime}\end{array}$ & 1882 \\
\hline 53 & Yeferenj shenkora & $31 / 08 / 2010$ & Esayas Tena & 40 & $\begin{array}{l}\text { SNNP/Dawro/Mareka/MedaKuli/ } \\
\text { Gendomeda }\end{array}$ & $\begin{array}{l}06^{\circ} 58.977^{\prime} / \\
037^{\circ} 11.493^{\prime}\end{array}$ & 1803 \\
\hline 54 & Yemaytafit Shenkora & 29/09/2010 & Esayas Tena & 56 & Oromia/Bale/Agarfa/Wabe & $\begin{array}{l}\text { Collected from } \\
\text { market }\end{array}$ & \\
\hline 55 & Kay Shenkora & $04 / 10 / 2010$ & Esayas Tena & 59 & $\begin{array}{l}\text { Oromia/Arsi/Tena/Kereyuharzuna } \\
\text { /Debenshe }\end{array}$ & $\begin{array}{l}07^{\circ} 42.648^{\prime} / \\
039^{\circ} 35.844^{\prime}\end{array}$ & 1848 \\
\hline 56 & Wotete & 02/10/2010 & Esayas Tena & 58 & Oromia/Arsi/Tio/Bosha & & market \\
\hline 57 & $\begin{array}{l}\text { Shenkora Dima/Kay } \\
\text { Shenkora }\end{array}$ & 29/09/2010 & Esayas Tena & 54 & Oromia/Bale/Agarfa/Alochefo/ & $\begin{array}{l}07^{\circ} 23.154^{\prime} / \\
039^{\circ} 46.271^{\prime}\end{array}$ & 1497 \\
\hline 58 & $\begin{array}{l}\text { Nach Shenkora/ } \\
\text { Shenkora Adi }\end{array}$ & 04/10/2010 & Esayas Tena & 61 & $\begin{array}{l}\text { Oromia/Arsi/Tena/Kereyuharzuna/ } \\
\text { Debenshe }\end{array}$ & $\begin{array}{l}07^{\circ} 42.648^{\prime} / \\
039^{\circ} 35.844^{\prime}\end{array}$ & 1848 \\
\hline 59 & Nach Shenkora & 29/09/2010 & Esayas Tena & 55 & $\begin{array}{c}\text { Oromia/Bale/Agarfa/Alochefo/ } \\
\text { Odachefo }\end{array}$ & $\begin{array}{l}07^{\circ} 23.154^{\prime} / \\
039^{\circ} 46.271^{\prime}\end{array}$ & 1497 \\
\hline 60 & Moris & 04/10/2010 & Esayas Tena & 60 & $\begin{array}{l}\text { Oromia/Arsi/Tena/Kereyuharzuna/ } \\
\text { Debenshe }\end{array}$ & $\begin{array}{l}07^{\circ} 42.648^{\prime} / \\
039^{\circ} 35.844^{\prime}\end{array}$ & 1848 \\
\hline 61 & Kay Shenkora & $30 / 09 / 2010$ & Esayas Tena & 57 & $\begin{array}{l}\text { Oromia/Bale/Goro/Melkabuta/Gadula } \\
\text { Gola Dhertu }\end{array}$ & $\begin{array}{l}06^{\circ} 58.539^{\prime} / \\
040^{\circ} 35.398^{\prime}\end{array}$ & 1611 \\
\hline 62 & $\begin{array}{l}\text { Ye Abesha Shenkora/ } \\
\text { Ye Oromo Shenkora }\end{array}$ & 08/10/2010 & Esayas Tena & 67 & Oromia/West Shewa/Ambo/Harutiro & $\begin{array}{l}09^{\circ} 07.613^{\prime} / \\
037^{\circ} 47.724^{\prime}\end{array}$ & 2370 \\
\hline 63 & Kay Shenkora/Wonji & 07/10/2010 & Esayas Tena & 65 & $\begin{array}{c}\text { Amhara/North Shewa/Debresina } \\
\text { Market }\end{array}$ & $\begin{array}{l}10^{\circ} 04.978^{\prime} / \\
039^{\circ} 53.606^{\prime}\end{array}$ & 1276 \\
\hline 64 & Nach Shenkora & 07/10/2010 & Esayas Tena & 66 & $\begin{array}{c}\text { Amhara/North Shewa/Debresina } \\
\text { Market }\end{array}$ & $\begin{array}{l}10^{\circ} 04.978^{\prime} / \\
039^{\circ} 53.606^{\prime}\end{array}$ & 1276 \\
\hline 65 & Tikur Ageda & 07/10/2010 & Esayas Tena & 62 & Amhara/North Shewa/Kewet/Yelen & $\begin{array}{l}10^{\circ} 04.978^{\prime} / \\
039^{\circ} 53.606^{\prime}\end{array}$ & 1235 \\
\hline 66 & Nach Ageda & $07 / 10 / 2010$ & Esayas Tena & 64 & Amhara/North Shewa/Kewet/Yelen & $\begin{array}{l}10^{\circ} 04.978^{\prime} / \\
039^{\circ} 53.606^{\prime}\end{array}$ & 1235 \\
\hline 67 & $\begin{array}{l}\text { Nach Kechacha } \\
\text { Shenkora/ Getr }\end{array}$ & 07/10/2010 & Esayas Tena & 63 & Amhara/North Shewa/Kewet/Yelen & $\begin{array}{l}10^{\circ} 04.978^{\prime} / \\
039^{\circ} 53.606^{\prime}\end{array}$ & 1235 \\
\hline 68 & Ye Bako Shenkora & 08/10/2010 & Esayas Tena & 68 & Oromia/West Shewa/Ambo/Harutiro & $\begin{array}{l}09^{\circ} 07.613^{\prime} / \\
037^{\circ} 47.724^{\prime}\end{array}$ & 2370 \\
\hline 69 & Bula Shenkora & 06/11/2010 & Esayas Tena & 77 & SNNP/Sheka/Masha/Shibo & $\begin{array}{l}07^{\circ} 44.641^{\prime} / \\
035^{\circ} 28.511^{\prime}\end{array}$ & 2277 \\
\hline 70 & $\begin{array}{l}\text { Kay Shenkora/ } \\
\text { Kadiken }\end{array}$ & $04 / 11 / 2010$ & Esayas Tena & 69 & Gambella/Agnwak/Abobo/Aberimeti & $\begin{array}{l}07^{\circ} 55.825^{\prime} / \\
034^{\circ} 43.133^{\prime}\end{array}$ & 507 \\
\hline 71 & Bicha Shenkora & 06/11/2010 & Esayas Tena & 76 & SNNP/Sheka/Masha/Beto & $\begin{array}{l}07^{\circ} 44.641^{\prime} / \\
035^{\circ} 28.511^{\prime}\end{array}$ & 2277 \\
\hline
\end{tabular}




\section{Continued}

\begin{tabular}{|c|c|c|c|c|c|c|c|}
\hline 72 & $\begin{array}{l}\text { Shenkora Dima/ } \\
\text { Kay Shenkora }\end{array}$ & 05/11/2010 & Esayas Tena & 73 & Oromia/Illubabor/Bure/Wengawobe & $\begin{array}{l}08^{\circ} 09.189^{\prime} / \\
035^{\circ} 27.382^{\prime}\end{array}$ & 1758 \\
\hline 73 & Kay Shenkora Ageda & 05/11/2010 & Esayas Tena & 72 & Oromia/Illubabor/Huka/Abyuadrere & $\begin{array}{l}08^{\circ} 13.781^{\prime} / \\
035^{\circ} 15.796^{\prime}\end{array}$ & 1600 \\
\hline 74 & $\begin{array}{l}\text { Nach Shenkora/ } \\
\text { Kadiken }\end{array}$ & $04 / 11 / 2010$ & Esayas Tena & 70 & Gambella/Agnwak/Abobo/Aberimeti & $\begin{array}{l}07^{\circ} 55.825^{\prime} / \\
034^{\circ} 43.133^{\prime}\end{array}$ & 507 \\
\hline 75 & Shenkora & 05/11/2010 & Esayas Tena & 71 & Gambella/Agnwak/Gog/Badabado & $\begin{array}{l}07^{\circ} 38.955^{\prime} / \\
034^{\circ} 15.386^{\prime}\end{array}$ & 454 \\
\hline 76 & Tikur Ageda & 08/11/2010 & Esayas Tena & 78 & SNNP/Sheka/Yeki/Addisbirhan & $\begin{array}{l}07^{\circ} 11.212^{\prime} / \\
035^{\circ} 26.095^{\prime}\end{array}$ & 1164 \\
\hline 77 & Ye Kenya Ageda & 06/11/2010 & Esayas Tena & 74 & SNNP/Sheka/Masha/Keja & $\begin{array}{l}07^{\circ} 50.149^{\prime} / \\
035^{\circ} 28.159^{\prime}\end{array}$ & 1827 \\
\hline 78 & Kay Ageda & 08/11/2010 & Esayas Tena & 79 & SNNP/Sheka/Yeki/Addisbirhan & $\begin{array}{l}07^{\circ} 11.212^{\prime} / \\
035^{\circ} 26.095^{\prime}\end{array}$ & 1164 \\
\hline 79 & Kay Shenkora/Dima & 02/11/2010 & Esayas Tena & $69-1$ & $\begin{array}{l}\text { Oromia/Jima Zone/Sekoru } \\
\text { Wereda/Habedode Kebele }\end{array}$ & $\begin{array}{l}\text { Collected from } \\
\text { market }\end{array}$ & \\
\hline 80 & Ye Kenya Shenkora & 06/11/2010 & Esayas Tena & 75 & SNNP/Sheka/Masha/Masha 01 & $\begin{array}{l}07^{\circ} 44.641^{\prime} / \\
035^{\circ} 28.511^{\prime}\end{array}$ & 2277 \\
\hline 81 & Kay Ageda & 09/11/2010 & Esayas Tena & 82 & SNNP/Kefa/Gimbo/Bonga 01 & $\begin{array}{l}07^{\circ} 15.225^{\prime} / \\
036^{\circ} 15.303^{\prime}\end{array}$ & 1792 \\
\hline 82 & Tikur Ageda & 08/11/2010 & Esayas Tena & 80 & $\begin{array}{l}\text { SNNP/Bench Majii /Mizan Teferi/ } \\
\text { Hibret Kebele }\end{array}$ & $\begin{array}{l}07^{\circ} 00.061^{\prime} / \\
035^{\circ} 35.802^{\prime}\end{array}$ & 1356 \\
\hline 83 & Shembeko Ageda & 09/11/2010 & Esayas Tena & 81 & SNNP/Kefa/Gimbo/Bonga 01 & $\begin{array}{l}07^{\circ} 15.225^{\prime} / \\
036^{\circ} 15.303^{\prime}\end{array}$ & 1792 \\
\hline 84 & Tikur Ageda & $12 / 11 / 2010$ & Esayas Tena & 84 & Oromia/Illubabor/Bilonopa/Suli & $\begin{array}{l}08^{\circ} 26.252^{\prime} / \\
035^{\circ} 36.267^{\prime}\end{array}$ & 1417 \\
\hline 85 & Nach Shenkora & $12 / 11 / 2010$ & Esayas Tena & 86 & Oromia/Illubabor/Bilonopa/Dizy & $\begin{array}{l}08^{\circ} 23.138^{\prime} / \\
035^{\circ} 36.249^{\prime}\end{array}$ & 1559 \\
\hline 87 & Dalecha Shenkora & $12 / 11 / 2010$ & Esayas Tena & 83 & Oromia/Illubabor/Bilonopa/Suli & $\begin{array}{l}08^{\circ} 26.252^{\prime} / \\
035^{\circ} 36.267^{\prime}\end{array}$ & 1417 \\
\hline 89 & Kay Shenkora Ageda & $12 / 11 / 2010$ & Esayas Tena & 85 & Oromia/Illubabor/Bilonopa/Suli & $\begin{array}{l}08^{\circ} 26.252^{\prime} / \\
035^{\circ} 36.267^{\prime}\end{array}$ & 1417 \\
\hline 90 & Kay Shenkora & $15 / 11 / 2010$ & Esayas Tena & 87 & $\begin{array}{l}\text { Oromia/Illubabor/Dureni/ } \\
\text { Betelegebecha/Hadere }\end{array}$ & $\begin{array}{l}08^{\circ} 29.860^{\prime} / \\
035^{\circ} 45.110^{\prime}\end{array}$ & 1754 \\
\hline 91 & Barbados & $22 / 12 / 2010$ & Esayas Tena & 97 & $\begin{array}{l}\text { Oromia/Gimbi/Laloasabe/ } \\
\text { Harochserdo Kebele }\end{array}$ & & \\
\hline 92 & Ye Bako Shenkora & $22 / 12 / 2010$ & Esayas Tena & 101 & $\begin{array}{l}\text { Oromia/Gimbi/Laloasabe/ } \\
\text { Dengoro 01/Golbe }\end{array}$ & $\begin{array}{l}09^{\circ} 16.130 \prime / \\
035^{\circ} 40.804^{\prime}\end{array}$ & 1730 \\
\hline 93 & Kay shenkora & $22 / 12 / 2010$ & Esayas Tena & 99 & $\begin{array}{l}\text { Oromia/Gimbi/Laloasabe/ } \\
\text { Dengoro 01/Golbe }\end{array}$ & $\begin{array}{l}09^{\circ} 16.130^{\prime} / \\
035^{\circ} 40.804^{\prime}\end{array}$ & 1730 \\
\hline 94 & Ageda Adi & 23/12/2010 & Esayas Tena & 106 & $\begin{array}{c}\text { Oromia/Kelem Welega/Sayo/ } \\
\text { Gelanometi/Sembo }\end{array}$ & $\begin{array}{l}08^{\circ} 32.704^{\prime} / \\
034^{\circ} 43.594^{\prime}\end{array}$ & 1730 \\
\hline 96 & Nech Shenkora & $22 / 12 / 2010$ & Esayas Tena & 100 & $\begin{array}{l}\text { Oromia/Gimbi/Laloasabe/ } \\
\text { Dengoro 01/Golbe }\end{array}$ & $\begin{array}{l}09^{\circ} 16.130^{\prime} / \\
035^{\circ} 40.804^{\prime}\end{array}$ & 1730 \\
\hline 97 & Tabor Shenkora & $23 / 12 / 2010$ & Esayas Tena & 102 & $\begin{array}{c}\text { Oromia/Gimbi/Guliso/Wereseyo/ } \\
\text { Kobera }\end{array}$ & $\begin{array}{l}09^{\circ} 10.256^{\prime} / \\
035^{\circ} 31.592^{\prime}\end{array}$ & 1484 \\
\hline
\end{tabular}




\section{Continued}

\begin{tabular}{|c|c|c|c|c|c|c|c|}
\hline 98 & $\begin{array}{l}\text { Nach Shenkora/Ye } \\
\text { Jima Shenkora }\end{array}$ & $21 / 12 / 2010$ & Esayas Tena & 95 & $\begin{array}{l}\text { Benshangulgumuz/Asosa/Bambasi } \\
\text { Mender } 49 \text { (Sefera Tabia) }\end{array}$ & $\begin{array}{l}09^{\circ} 49.520^{\prime} / \\
034^{\circ} 41.766^{\prime}\end{array}$ & 1415 \\
\hline 99 & Shilmu & $23 / 12 / 2010$ & Esayas Tena & 104 & $\begin{array}{l}\text { Oromia/Kelem Welega/Dale } \\
\text { Wabera/Chanka Burore }\end{array}$ & $\begin{array}{l}08^{\circ} 49.268^{\prime} / \\
035^{\circ} 03.747^{\prime}\end{array}$ & 1470 \\
\hline 100 & Nach Shenkora & $24 / 12 / 2010$ & Esayas Tena & 107 & $\begin{array}{c}\text { Oromia/Kelem } \\
\text { Welega/Hawagelan/Haromechara }\end{array}$ & $\begin{array}{l}08^{\circ} 43.544^{\prime} / \\
034^{\circ} 59.141^{\prime}\end{array}$ & 1444 \\
\hline 101 & Kay Shenkora & $27 / 12 / 2010$ & Esayas Tena & 110 & $\begin{array}{c}\text { Oromia/West } \\
\text { Shewa/Bakotibe/Dembigobu }\end{array}$ & $\begin{array}{l}09^{\circ} 07.616^{\prime} / \\
037^{\circ} 04.565^{\prime}\end{array}$ & 1620 \\
\hline 103 & Nach Shenkora & $24 / 12 / 2010$ & Esayas Tena & 108 & $\begin{array}{c}\text { Oromia/Kelem } \\
\text { Welega/Hawagelan/Haromechara }\end{array}$ & $\begin{array}{l}08^{\circ} 43.544^{\prime} / \\
034^{\circ} 59.141^{\prime}\end{array}$ & 1444 \\
\hline 104 & Burabure Shenkora & $20 / 12 / 2010$ & Esayas Tena & 93 & $\begin{array}{l}\text { Benshangulgumuz/Asosa/ } \\
\text { Megele } 32 \text { (Sefera Tabia) }\end{array}$ & $\begin{array}{l}10^{\circ} 01.179^{\prime} / \\
034^{\circ} 32.705^{\prime}\end{array}$ & 1478 \\
\hline 105 & Nach Shenkora & 20/12/2010 & Esayas Tena & 92 & $\begin{array}{l}\text { Benshangulgumuz/Asosa/ } \\
\text { Megele 32(Sefera Tabia) }\end{array}$ & $\begin{array}{l}10^{\circ} 01.179^{\prime} / \\
034^{\circ} 32.705^{\prime}\end{array}$ & 1478 \\
\hline 106 & Abesha Shenkora/Adi & $27 / 12 / 2010$ & Esayas Tena & 109 & $\begin{array}{c}\text { Oromia/West } \\
\text { Shewa/Bakotibe/Dembigobu }\end{array}$ & $\begin{array}{l}09^{\circ} 07.616^{\prime} / \\
037^{\circ} 04.565^{\prime}\end{array}$ & 1620 \\
\hline 107 & Nach Shenkora & 03/02/2011 & Esayas Tena & 116 & $\begin{array}{c}\text { Amhara/Debub Gondar/ } \\
\text { Derra/Mashenkoro/Misgano }\end{array}$ & $\begin{array}{l}11^{\circ} 42.976^{\prime} / \\
037^{\circ} 36.908\end{array}$ & 1993 \\
\hline 110 & Yegojam Shenkora & 02/02/2011 & Esayas Tena & 113 & $\begin{array}{l}\text { Amhara/Debub Gondar/ } \\
\text { Fogera/Wagtera }\end{array}$ & $\begin{array}{l}11^{\circ} 54.574^{\prime} / \\
037^{\circ} 33.371^{\prime}\end{array}$ & 1797 \\
\hline 111 & Tikur Shenkora & 04/02/2011 & Esayas Tena & 118 & $\begin{array}{c}\text { Amhara/West Gojam/Bahirdar Zuria/ } \\
\text { Tis Abay/Gebere Mahiber }\end{array}$ & $\begin{array}{l}11^{\circ} 29.128^{\prime} / \\
037^{\circ} 34.331^{\prime}\end{array}$ & 1642 \\
\hline 113 & Shilmlm Sora & 04/02/2011 & Esayas Tena & 120 & $\begin{array}{c}\text { Amhara/West Gojam/Bahirdar Zuria/ } \\
\text { Tis Abay/Gebere Mahiber }\end{array}$ & $\begin{array}{l}11^{\circ} 29.128^{\prime} / \\
037^{\circ} 34.331^{\prime}\end{array}$ & 1642 \\
\hline 114 & Ye Bure Shenkora & 04/02/2011 & Esayas Tena & 121 & $\begin{array}{c}\text { Amhara/West Gojam/Bahirdar Zuria/ } \\
\text { Tis Abay/Gebere Mahiber }\end{array}$ & $\begin{array}{l}11^{\circ} 29.128^{\prime} / \\
037^{\circ} 34.331^{\prime}\end{array}$ & 1642 \\
\hline 115 & Nach Ageda & 08/02/2011 & Esayas Tena & 122 & $\begin{array}{l}\text { Amhara/West Gojam/Jabitehnan/ } \\
\text { Mankusa Abdegom/Endalah }\end{array}$ & $\begin{array}{l}10^{\circ} 41.075^{\prime} / \\
037^{\circ} 11.357^{\prime}\end{array}$ & 1941 \\
\hline 116 & Tikur Shenkora & 08/02/2011 & Esayas Tena & 123 & $\begin{array}{l}\text { Amhara/West Gojam/Jabitehnan/ } \\
\text { Mankusa Abdegom/Endalah }\end{array}$ & $\begin{array}{l}10^{\circ} 41.075^{\prime} / \\
037^{\circ} 11.357^{\prime}\end{array}$ & 1941 \\
\hline 117 & Nach Shenkora/Sendel & 09/02/2011 & Esayas Tena & 124 & $\begin{array}{c}\text { Amhara/West Gojam/Debub } \\
\text { Achefer/Lalibela/Azena }\end{array}$ & $\begin{array}{l}11^{\circ} 28.590^{\prime} / \\
036^{\circ} 57.027^{\prime}\end{array}$ & 1883 \\
\hline 118 & $\begin{array}{c}\text { Nach Yemailat } \\
\text { Shenkora/ CO } 1001\end{array}$ & 09/02/2011 & Esayas Tena & 125 & $\begin{array}{l}\text { Amhara/West Gojam/Debub } \\
\text { Achefer/Lalibela/Azena }\end{array}$ & $\begin{array}{l}11^{\circ} 28.590^{\prime} / \\
036^{\circ} 57.027^{\prime}\end{array}$ & 1883 \\
\hline 119 & Bule/ B52 & 09/02/2011 & Esayas Tena & 126 & $\begin{array}{l}\text { Amhara/West Gojam/Debub } \\
\text { Achefer/Lalibela/Azena }\end{array}$ & $\begin{array}{l}11^{\circ} 28.590^{\prime} / \\
036^{\circ} 57.027^{\prime}\end{array}$ & 1883 \\
\hline 121 & Nach Shenkora & 09/02/2011 & Esayas Tena & $124-1$ & $\begin{array}{l}\text { Amhara/West Gojam/Debub } \\
\text { Achefer/Lalibela/Azena }\end{array}$ & $\begin{array}{l}11^{\circ} 28.590^{\prime} / \\
036^{\circ} 57.027^{\prime}\end{array}$ & 1883 \\
\hline 122 & Nach Shenkora & $15 / 02 / 2011$ & Esayas Tena & 129 & $\begin{array}{c}\text { BenshangulGumuz/Metekel/Pawe/ } \\
\text { Mender 28/29 }\end{array}$ & $\begin{array}{l}11^{\circ} 16.526^{\prime} / \\
036^{\circ} 27.233^{\prime}\end{array}$ & 1097 \\
\hline 123 & Kay Shenkora & $17 / 02 / 2011$ & Esayas Tena & 134 & $\begin{array}{c}\text { Amhara/Awi/Guangua/Mota/ } \\
\text { Menta Wuha }\end{array}$ & $\begin{array}{l}10^{\circ} 50.310^{\prime} / \\
036^{\circ} 20.642^{\prime}\end{array}$ & 1532 \\
\hline 124 & Kay Shenkora & $15 / 02 / 2011$ & Esayas Tena & 128 & $\begin{array}{c}\text { BenshangulGumuz/Metekel/Pawe/ } \\
\text { Mender 28/29 }\end{array}$ & $\begin{array}{l}11^{\circ} 16.526^{\prime} / \\
036^{\circ} 27.233^{\prime}\end{array}$ & 1097 \\
\hline 126 & Nach Shenkora & $17 / 02 / 2011$ & Esayas Tena & 133 & $\begin{array}{l}\text { Amhara/Awi/Guangua/Mota/ } \\
\text { Menta Wuha }\end{array}$ & $\begin{array}{l}10^{\circ} 50.310^{\prime} / \\
036^{\circ} 20.642^{\prime}\end{array}$ & 1532 \\
\hline 127 & $\begin{array}{l}\text { Nach Shenkora/ } \\
\text { Bishoftu/ China }\end{array}$ & $21 / 02 / 2011$ & Esayas Tena & 138 & $\begin{array}{l}\text { Amhara/East Gojam/ } \\
\text { Dejen/Kurar/Dengel }\end{array}$ & $\begin{array}{l}10^{\circ} 06.578^{\prime} / \\
038^{\circ} 09.202^{\prime}\end{array}$ & 1820 \\
\hline
\end{tabular}




\section{Continued}

\begin{tabular}{|c|c|c|c|c|c|c|c|}
\hline 128 & $\begin{array}{c}\text { Gojame/Ye Gojam } \\
\text { Ageda }\end{array}$ & $21 / 02 / 2011$ & Esayas Tena & 141 & $\begin{array}{c}\text { Amhara/East Gojam/ } \\
\text { Dejen/Kurar/Ambayamit }\end{array}$ & $\begin{array}{l}10^{\circ} 06.490^{\prime} / \\
038^{\circ} 09.185^{\prime}\end{array}$ & 1804 \\
\hline 129 & Nach Shenkora & $21 / 02 / 2011$ & Esayas Tena & 139 & $\begin{array}{l}\text { Amhara/East Gojam/ } \\
\text { Dejen/Kurar/Dengel }\end{array}$ & $\begin{array}{l}10^{\circ} 06.578^{\prime} / \\
038^{\circ} 09.202^{\prime}\end{array}$ & 1820 \\
\hline 131 & $\begin{array}{l}\text { Kay Shenkora/ } \\
\text { Bishoftu }\end{array}$ & $21 / 02 / 2011$ & Esayas Tena & 137 & $\begin{array}{l}\text { Amhara/East Gojam/ } \\
\text { Dejen/Kurar/Dengel }\end{array}$ & $\begin{array}{l}10^{\circ} 06.578^{\prime} / \\
038^{\circ} 09.202^{\prime}\end{array}$ & 1820 \\
\hline 132 & Abadir & $21 / 02 / 2011$ & Esayas Tena & 142 & $\begin{array}{c}\text { Amhara/East Gojam/ } \\
\text { Dejen/Kurar/Ambayamit }\end{array}$ & $\begin{array}{l}10^{\circ} 06.490^{\prime} / \\
038^{\circ} 09.185^{\prime}\end{array}$ & 1804 \\
\hline 133 & Ye Fincha Shenkora & 23/02/2011 & Esayas Tena & 144 & $\begin{array}{c}\text { Amhara/East Gojam/ } \\
\text { Basoliben/Entemen Dejat }\end{array}$ & $\begin{array}{l}10^{\circ} 03.504^{\prime} / \\
037^{\circ} 50.264^{\prime}\end{array}$ & 2360 \\
\hline 134 & Kay Ageda & $22 / 02 / 2011$ & Esayas Tena & 143 & $\begin{array}{c}\text { Amhara/East Gojam/Dejen/ } \\
\text { Dejen Town }\end{array}$ & & \\
\hline 136 & Bicha Shenkora & 21/02/2011 & Esayas Tena & 140 & $\begin{array}{l}\text { Amhara/East Gojam/ } \\
\text { Dejen/Kurar/Dengel }\end{array}$ & $\begin{array}{l}10^{\circ} 06.578^{\prime} / \\
038^{\circ} 09.202^{\prime}\end{array}$ & 1820 \\
\hline 138 & Kay Ageda & $21 / 04 / 2011$ & Esayas Tena & 148 & $\begin{array}{c}\text { Tigray/Semen Mierab Tigray/Tach } \\
\text { Koraro/Semena/Maymesreb }\end{array}$ & $\begin{array}{l}14^{\circ} 11.602^{\prime} / \\
038^{\circ} 20.897^{\prime}\end{array}$ & 1927 \\
\hline 139 & Kay Shenkora & 21/04/2011 & Esayas Tena & 146 & $\begin{array}{c}\text { Tigray/Central Tigray/Tahtay } \\
\text { Maychew/Mayatsmi }\end{array}$ & $\begin{array}{l}14^{\circ} 04.680^{\prime} / \\
038^{\circ} 33.366^{\prime}\end{array}$ & 1993 \\
\hline 140 & Kay Ageda & 21/04/2011 & Esayas Tena & 150 & $\begin{array}{c}\text { Tigray/Semen Mierab Tigray/Tach } \\
\text { Koraro/Semena/Maymesreb }\end{array}$ & $\begin{array}{l}14^{\circ} 11.602^{\prime} / \\
038^{\circ} 20.897^{\prime}\end{array}$ & 1927 \\
\hline 141 & Nach Shenkora & 21/04/2011 & Esayas Tena & 147 & $\begin{array}{c}\text { Tigray/Central Tigray/Tahtay } \\
\text { Maychew/Mayatsmi }\end{array}$ & $\begin{array}{l}14^{\circ} 04.680^{\prime} / \\
038^{\circ} 33.366^{\prime}\end{array}$ & 1993 \\
\hline 142 & Kay Ageda & $21 / 04 / 2011$ & Esayas Tena & 149 & $\begin{array}{c}\text { Tigray/Semen Mierab Tigray/Tach } \\
\text { Koraro/Semena/Maymesreb }\end{array}$ & $\begin{array}{l}14^{\circ} 11.602^{\prime} / \\
038^{\circ} 20.897^{\prime}\end{array}$ & 1927 \\
\hline 143 & Nach Ageda/ Shenkora & 26/04/2011 & Esayas Tena & 152 & $\begin{array}{c}\text { Amhara/Semen } \\
\text { Welo/Gubalafto/Woynye 011/Medakit }\end{array}$ & $\begin{array}{l}11^{\circ} 53.630^{\prime} / \\
039^{\circ} 28.136^{\prime}\end{array}$ & 2030 \\
\hline 144 & Kay Ageda/ Shenkora & 26/04/2011 & Esayas Tena & 151 & $\begin{array}{c}\text { Amhara/Semen Welo/Gubalafto/ } \\
\text { Woynye 011/Medakit }\end{array}$ & $\begin{array}{l}11^{\circ} 53.630^{\prime} / \\
039^{\circ} 28.136^{\prime}\end{array}$ & 2030 \\
\hline 145 & $\begin{array}{l}\text { Kay Shenkora (Bu- } \\
\text { rabure) }\end{array}$ & 04/05/2011 & Esayas Tena & 159 & $\begin{array}{c}\text { Amhara/Semen Welo/Habru/09 } \\
\text { Kebele/Ante }\end{array}$ & $\begin{array}{l}11^{\circ} 41.085^{\prime} / \\
039^{\circ} 38.325^{\prime}\end{array}$ & 1695 \\
\hline 146 & $\begin{array}{l}\text { Nach Ye Abesha } \\
\text { Shenkora }\end{array}$ & 04/05/2011 & Esayas Tena & 160 & $\begin{array}{c}\text { Amhara/Semen Welo/Habru/09 } \\
\text { Kebele/Ante }\end{array}$ & $\begin{array}{l}11^{\circ} 41.085^{\prime} / \\
039^{\circ} 38.325^{\prime}\end{array}$ & 1695 \\
\hline 149 & Nach Tilik Shenkora & 03/05/2011 & Esayas Tena & 158 & $\begin{array}{c}\text { Amhara/Debub Welo/Werebabo/ } \\
02 \text { kebele/Bulbulo/Aselel Prim. School }\end{array}$ & $\begin{array}{l}11^{\circ} 19.354^{\prime} / \\
039^{\circ} 45.074^{\prime}\end{array}$ & 2072 \\
\hline 150 & Nach Shenkora & 29/04/2011 & Esayas Tena & 154 & $\begin{array}{c}\text { Amhara/Oromia Special } \\
\text { Zone/Kemissie/02 Kebele/Ergi }\end{array}$ & $\begin{array}{l}10^{\circ} 42.491^{\prime} / \\
039^{\circ} 51.712^{\prime}\end{array}$ & 1422 \\
\hline 151 & Nach Ageda & 02/05/2011 & Esayas Tena & 155 & $\begin{array}{c}\text { Amhara/Debub Welo/Borena/04 } \\
\text { Kebele/Jimaye }\end{array}$ & $\begin{array}{l}10^{\circ} 45.172^{\prime} / \\
038^{\circ} 45.974^{\prime}\end{array}$ & 2687 \\
\hline 152 & Nach Tinish Shenkora & 03/05/2011 & Esayas Tena & 157 & $\begin{array}{c}\text { Amhara/Debub Welo/Werebabo/ } \\
02 \text { Kebele/Bulbulo/Aselel Prim. School }\end{array}$ & $\begin{array}{l}11^{\circ} 19.354^{\prime} / \\
039^{\circ} 45.074^{\prime}\end{array}$ & 2072 \\
\hline 153 & Ye Beskula Shenkora & 02/05/2011 & Esayas Tena & $155-1$ & $\begin{array}{c}\text { Amhara Region/South Welo } \\
\text { Zone/Legambo Wereda/Beskula } \\
\text { Kebele }\end{array}$ & $\begin{array}{l}\text { Collected from } \\
\text { market }\end{array}$ & \\
\hline 154 & Nach Shenkora & 29/04/2011 & Esayas Tena & 153 & $\begin{array}{c}\text { Amhara/Oromia Special } \\
\text { Zone/Kemissie/02 Kebele/Ergi }\end{array}$ & $\begin{array}{l}10^{\circ} 42.491^{\prime} / \\
039^{\circ} 51.712^{\prime}\end{array}$ & 1422 \\
\hline 155 & $\begin{array}{l}\text { Nach Ye Abesha } \\
\text { Shenkora }\end{array}$ & 05/05/2011 & Esayas Tena & 163 & $\begin{array}{c}\text { Amhara/Semen Welo/Meket/013 } \\
\text { Kebele/Emamoz Fikrte Kirstos Gedam }\end{array}$ & & \\
\hline 156 & Nach Ageda/ Shenkora & 09/05/2011 & Esayas Tena & 164 & $\begin{array}{c}\text { Amhara/Waghmra/Sekota/02 } \\
\text { Kebele/Tiya }\end{array}$ & $\begin{array}{l}12^{\circ} 30.391^{\prime} / \\
039^{\circ} 05.795^{\prime}\end{array}$ & 1978 \\
\hline
\end{tabular}




\section{Continued}

\begin{tabular}{|c|c|c|c|c|c|c|c|}
\hline 157 & Kay Ageda/Shenkora & 09/05/2011 & Esayas Tena & 166 & Tigray/Debub Tigray/Ofla/Zata & $\begin{array}{l}12^{\circ} 30.924^{\prime} / \\
039^{\circ} 16.477^{\prime}\end{array}$ & 2134 \\
\hline 158 & Ancha & 09/05/2011 & Esayas Tena & 165 & Tigray/Debub Tigray/Ofla/Zata & $\begin{array}{l}12^{\circ} 30.924^{\prime} / \\
039^{\circ} 16.477^{\prime}\end{array}$ & 2134 \\
\hline 159 & Nach Shenkora & 22/06/2011 & Esayas Tena & 177 & $\begin{array}{c}\text { Oromia/East Hararghe/Gurawa/01 } \\
\text { Kebele/Kera Sefer }\end{array}$ & $\begin{array}{l}09^{\circ} 08.392^{\prime} / \\
041^{\circ} 50.424^{\prime}\end{array}$ & 2401 \\
\hline 160 & Shenkora Adi & $22 / 06 / 2011$ & Esayas Tena & 175 & $\begin{array}{l}\text { Oromia/East Hararghe/ } \\
\text { Kurfachele/Dawe/ }\end{array}$ & $\begin{array}{l}09^{\circ} 17.423^{\prime} / \\
041^{\circ} 52.611^{\prime}\end{array}$ & 1713 \\
\hline 161 & Nach Shenkora & 23/06/2011 & Esayas Tena & 178 & $\begin{array}{l}\text { Oromia/East Hararghe/Meta/Chelenko } \\
02 \text { kebele }\end{array}$ & $\begin{array}{l}09^{\circ} 23.875^{\prime} / \\
041^{\circ} 33.670^{\prime}\end{array}$ & 2179 \\
\hline 162 & Shenkora Dima & $22 / 06 / 2011$ & Esayas Tena & 176 & $\begin{array}{l}\text { Oromia/East Hararghe/ } \\
\text { Kurfachele/Dawe/ }\end{array}$ & $\begin{array}{l}09^{\circ} 17.423 \prime / \\
041^{\circ} 52.611^{\prime}\end{array}$ & 1713 \\
\hline 163 & Nach Shenkora/Wonji & 23/06/2011 & Esayas Tena & 180 & $\begin{array}{l}\text { Oromia/East Hararghe/Meta/ } \\
\text { Chelenko } 02 \text { kebele }\end{array}$ & $\begin{array}{l}09^{\circ} 23.875^{\prime} / \\
041^{\circ} 33.670^{\prime}\end{array}$ & 2179 \\
\hline 164 & $\begin{array}{l}\text { Yemilat Nach } \\
\text { Shenkora }\end{array}$ & 23/06/2011 & Esayas Tena & 179 & $\begin{array}{l}\text { Oromia/East Hararghe/Meta/Chelenko } \\
\text { 02 Kebele }\end{array}$ & $\begin{array}{l}09^{\circ} 23.875^{\prime} / \\
041^{\circ} 33.670^{\prime}\end{array}$ & 2179 \\
\hline 165 & Nach Shenkora & 21/06/2011 & Esayas Tena & 173 & $\begin{array}{c}\text { Harari/Erer Wereda/Dodota Kebele/ } \\
\text { Mudir Village }\end{array}$ & $\begin{array}{l}09^{\circ} 19.353^{\prime} / \\
042^{\circ} 13.030^{\prime}\end{array}$ & 1376 \\
\hline 166 & Burabure Shenkora & $21 / 06 / 2011$ & Esayas Tena & 174 & $\begin{array}{c}\text { Harari/Erer Wereda/Dodota Kebele/ } \\
\text { Mudir Village }\end{array}$ & $\begin{array}{l}09^{\circ} 19.353^{\prime} / \\
042^{\circ} 13.030^{\prime}\end{array}$ & 1376 \\
\hline 167 & Kay Shenkora & 20/06/2011 & Esayas Tena & 168 & $\begin{array}{c}\text { Oromia/East Hararghe/ } \\
\text { Babile/Ererguda/ } \\
\text { Megida }\end{array}$ & $\begin{array}{l}09^{\circ} 14.783^{\prime} / \\
042^{\circ} 15.022^{\prime}\end{array}$ & 1315 \\
\hline 169 & $\begin{array}{c}\text { Kay } \\
\text { Shenkora/Burabure }\end{array}$ & 20/06/2011 & Esayas Tena & $168-1$ & $\begin{array}{l}\text { Oromia/East Hararghe/ } \\
\text { Babile/Ererguda/Megida }\end{array}$ & $\begin{array}{l}09^{\circ} 14.783^{\prime} / \\
042^{\circ} 15.022^{\prime}\end{array}$ & 1315 \\
\hline 170 & Kay Shenkora & 20/06/2011 & Esayas Tena & 171 & $\begin{array}{l}\text { Oromia/East Hararghe/ } \\
\text { Kombolcha/Sibilu/ } \\
\text { Gende Wedo Usman }\end{array}$ & $\begin{array}{l}09^{\circ} 25.248^{\prime} / \\
042^{\circ} 06.965^{\prime}\end{array}$ & 2113 \\
\hline 171 & $\begin{array}{l}\text { Kay Shenkora/ } \\
\text { Burabure }\end{array}$ & 23/06/2011 & Esayas Tena & 181 & $\begin{array}{l}\text { Oromia/East Hararghe/Gorogutu/ } \\
\text { Erermedanchine/Ginge }\end{array}$ & $\begin{array}{l}09^{\circ} 24.966^{\prime} / \\
041^{\circ} 29.590^{\prime}\end{array}$ & 1728 \\
\hline 172 & $\begin{array}{l}\text { Guracha Shenkora/ } \\
\text { Tikur }\end{array}$ & 20/06/2011 & Esayas Tena & 169 & $\begin{array}{c}\text { Oromia/East } \\
\text { Harerge/Babile/Ererguda/Megida }\end{array}$ & $\begin{array}{l}09^{\circ} 14.783^{\prime} / \\
042^{\circ} 15.022\end{array}$ & 1315 \\
\hline 173 & Misrah & 29/06/2011 & Esayas Tena & 187 & $\begin{array}{l}\text { Oromia/West Hararghe/Gemechis/ } \\
\text { Wemecho Dayo/Dekadabu }\end{array}$ & $\begin{array}{l}08^{\circ} 45.408^{\prime} / \\
040^{\circ} 53.285^{\prime}\end{array}$ & 1496 \\
\hline 174 & Wonji & 29/06/2011 & Esayas Tena & 186 & $\begin{array}{c}\text { Oromia/West Hararghe/ } \\
\text { Gemechis/Wemecho Dayo/Dekadabu }\end{array}$ & $\begin{array}{l}08^{\circ} 45.408^{\prime} / \\
040^{\circ} 53.285^{\prime}\end{array}$ & 1496 \\
\hline 175 & $\begin{array}{l}\text { Wonji/Bula/ } \\
\text { Shenkora Adi }\end{array}$ & 28/06/2011 & Esayas Tena & 184 & $\begin{array}{l}\text { Oromia/West Hararghe/Gubakoricha/ } \\
\text { Oda Aneni } 05 \text { kebele/Nanofaro }\end{array}$ & $\begin{array}{l}08^{\circ} 56.717^{\prime} / \\
040^{\circ} 33.308^{\prime}\end{array}$ & 1972 \\
\hline 176 & Shekole & 28/06/2011 & Esayas Tena & 182 & $\begin{array}{l}\text { Oromia/West Hararghe/Gubakoricha/ } \\
\text { Oda Aneni } 05 \text { kebele/Nanofaro }\end{array}$ & $\begin{array}{l}08^{\circ} 56.717^{\prime} / \\
040^{\circ} 33.308^{\prime}\end{array}$ & 1972 \\
\hline 177 & Holland & $30 / 06 / 2011$ & Esayas Tena & 188 & Oromia/West Hararghe/Darolebu & $\begin{array}{l}08^{\circ} 36.352^{\prime} / \\
040^{\circ} 19.278^{\prime}\end{array}$ & 1751 \\
\hline 178 & Bure & 28/06/2011 & Esayas Tena & 185 & $\begin{array}{l}\text { Oromia/West Hararghe/Gubakoricha/ } \\
\text { Oda Aneni } 05 \text { kebele/Nanofaro }\end{array}$ & $\begin{array}{l}08^{\circ} 56.717^{\prime} / \\
040^{\circ} 33.308^{\prime}\end{array}$ & 1972 \\
\hline
\end{tabular}




\section{Continued}

\begin{tabular}{|c|c|c|c|c|c|c|c|}
\hline 179 & Shenkora Dima & 01/07/2011 & Esayas Tena & 189 & $\begin{array}{c}\text { Oromia/West Hararghe/ } \\
\text { Mesela/Lubudekeb/Deneba }\end{array}$ & $\begin{array}{l}09^{\circ} 05.913^{\prime} / \\
041^{\circ} 08.151^{\prime}\end{array}$ & 1647 \\
\hline 180 & Wonji & 01/07/2011 & Esayas Tena & 190 & $\begin{array}{c}\text { Oromia/West Hararghe/ } \\
\text { Mesela/Lubudekeb/Deneba }\end{array}$ & $\begin{array}{l}09^{\circ} 05.913^{\prime} / \\
041^{\circ} 08.151^{\prime}\end{array}$ & 1647 \\
\hline 181 & Gende Lega & 28/06/2011 & Esayas Tena & 183 & $\begin{array}{l}\text { Oromia/West Hararghe/Gubakoricha/ } \\
\text { Oda Aneni } 05 \text { kebele/Nanofaro }\end{array}$ & $\begin{array}{l}08^{\circ} 56.717^{\prime} / \\
040^{\circ} 33.308^{\prime}\end{array}$ & 1972 \\
\hline 182 & Dikala & 06/07/2011 & Esayas Tena & 196 & $\begin{array}{l}\text { Oromia/East Hararghe/Deder/Kiyo } \\
\text { (Nedi Gelan Sedi)/Tulu }\end{array}$ & $\begin{array}{l}09^{\circ} 15.638^{\prime} / \\
041^{\circ} 23.451^{\prime}\end{array}$ & 1812 \\
\hline 183 & Alaa & 06/07/2011 & Esayas Tena & 194 & $\begin{array}{l}\text { Oromia/East Hararghe/Deder/Kiyo } \\
\text { (Nedi Gelan Sedi)/Tulu }\end{array}$ & $\begin{array}{l}09^{\circ} 15.638^{\prime} / \\
041^{\circ} 23.451^{\prime}\end{array}$ & 1812 \\
\hline 184 & Bure & 06/07/2011 & Esayas Tena & 191 & Somali/Shinele/Erer/Bila & $\begin{array}{l}09^{\circ} 31.774^{\prime} / \\
041^{\circ} 24.965^{\prime}\end{array}$ & 1192 \\
\hline 185 & Bure & 06/07/2011 & Esayas Tena & $191-1$ & Somali/Shinele/Erer/Gota & $\begin{array}{l}\text { Collected from } \\
\text { market }\end{array}$ & \\
\hline 186 & Shenkora Dima & 06/07/2011 & Esayas Tena & 192 & Somali/Shinele/Erer/Bila & $\begin{array}{l}09^{\circ} 31.774^{\prime} / \\
041^{\circ} 24.965^{\prime}\end{array}$ & 1192 \\
\hline 187 & Shenkora Adi & 08/07/2011 & Esayas Tena & $198-1$ & $\begin{array}{l}\text { Oromia/Eastern Haraghe } \\
\text { Zone/Meta/Ramis }\end{array}$ & $\begin{array}{l}\text { Collected from } \\
\text { market }\end{array}$ & \\
\hline 188 & Aladi & 06/07/2011 & Esayas Tena & 195 & $\begin{array}{l}\text { Oromia/East Hararghe/Deder/Kiyo } \\
\text { (Nedi Gelan Sedi)/Tulu }\end{array}$ & $\begin{array}{l}09^{\circ} 15.638^{\prime} / \\
041^{\circ} 23.451^{\prime}\end{array}$ & 1812 \\
\hline 189 & Erero & 06/07/2011 & Esayas Tena & 193 & $\begin{array}{l}\text { Oromia/East Hararghe/Deder/Kiyo } \\
\text { (Nedi Gelan Sedi)/Tulu }\end{array}$ & $\begin{array}{l}09^{\circ} 15.638^{\prime} / \\
041^{\circ} 23.451^{\prime}\end{array}$ & 1812 \\
\hline 190 & Engda & 07/07/2011 & Esayas Tena & 197 & $\begin{array}{c}\text { Oromia/West Hararghe/ } \\
\text { Anchar/Chorchora/Megala Deye } \\
\text { Market }\end{array}$ & $\begin{array}{l}08^{\circ} 47.508^{\prime} / \\
040^{\circ} 17.063\end{array}$ & 1690 \\
\hline 191 & Kay Shenkora & 07/07/2011 & Esayas Tena & 198 & $\begin{array}{c}\text { Oromia/West Hararghe/ } \\
\text { Anchar/Chorchora/Megala Deye } \\
\text { Market }\end{array}$ & $\begin{array}{l}08^{\circ} 47.508^{\prime} / \\
040^{\circ} 17.063\end{array}$ & 1690 \\
\hline
\end{tabular}

Appendix 2. Introduced sugarcane varieties in Ethiopia used for the study.

\begin{tabular}{|c|c|c|c|c|c|c|c|c|c|c|c|}
\hline $\begin{array}{l}\text { Code } \\
\text { Number }\end{array}$ & Cultivar & $\begin{array}{c}\text { Country of } \\
\text { origin }\end{array}$ & $\begin{array}{c}\text { Year of } \\
\text { introduction }\end{array}$ & $\begin{array}{c}\text { Code } \\
\text { Number }\end{array}$ & Cultivar & $\begin{array}{c}\text { Country of } \\
\text { origin }\end{array}$ & $\begin{array}{c}\text { Year of } \\
\text { introduction }\end{array}$ & $\begin{array}{c}\text { Code } \\
\text { Number }\end{array}$ & Cultivar & $\begin{array}{c}\text { Country of } \\
\text { origin }\end{array}$ & $\begin{array}{c}\text { Year of } \\
\text { introduction }\end{array}$ \\
\hline 192 & B3172 & Barbados & 1983 & 219 & В 51321 & Barbados & 1974 & 246 & BO 10 & $\begin{array}{c}\text { Bihar-Orissa } \\
\text { (India) }\end{array}$ & 1960 \\
\hline 193 & B35269 & Do & 1983 & 220 & В 51410 & Do & 1983 & 247 & BO 11 & Bihar-Orissa & 1960 \\
\hline 194 & B37172 & Do & 1956 & 221 & В 51415 & Do & 1974 & 248 & BO 14 & Do & 1974 \\
\hline 195 & B39250 & Do & 1983 & 222 & В 52107 & Do & 1974 & 249 & BO 29 & Do & 1974 \\
\hline 196 & B39254 & Do & 1983 & 223 & В 52158 & Do & 1970 & 250 & BO 3 & Do & 1970 \\
\hline 197 & В 4098 & Do & 1960 & 224 & В 52298 & Do & 1965 & 251 & BO60349 & Do & Unknown \\
\hline 198 & B41211 & Do & 1970 & 225 & В 52313 & Do & 1974 & 252 & CB 36-14 & $\begin{array}{l}\text { Campos } \\
\text { (Brazil) }\end{array}$ & 1974 \\
\hline 199 & В 4122 & Do & Unknown & 226 & В 53163 & Do & 1974 & 253 & CB 38-22 & Do & 1959 \\
\hline 200 & В 41227 & Do & 1957 & 227 & В 53164 & Do & 1974 & 254 & CB 38-39 & Do & 1959 \\
\hline 201 & B 42231 & Do & 1957 & 228 & В 5364 & Do & 1965 & 255 & CB 40-35 & Do & 1983 \\
\hline 202 & В 4362 & Do & 1957 & 229 & В 54142 & Do & 1974 & 257 & CB 41-76 & Do & 1970 \\
\hline 203 & В 4425 & Do & 1974 & 230 & В 5490 & Do & 1974 & 259 & CB 47-15 & Do & 1959 \\
\hline
\end{tabular}




\section{Continued}

\begin{tabular}{|c|c|c|c|c|c|c|c|c|c|c|c|}
\hline 204 & В 45154 & Do & 1974 & 231 & В 57133 & Do & 1974 & 260 & C $105-73$ & Cuba & 2003 \\
\hline 205 & В 45154 & Do & 1957 & 232 & В 57141 & Do & 1974 & 263 & CO 245 & Coimbatore & 1970 \\
\hline 206 & В 456 & Do & Unknown & 233 & В $80-250$ & Do & unknown & 264 & CO 331 & Do & 1954 \\
\hline 207 & В 47386 & Do & 1974 & 234 & В 5736 & Do & 1974 & 265 & CO 419 & Do & 1954 \\
\hline 208 & В 47419 & Do & 1957 & 235 & В 5780 & Do & 1974 & 266 & $\mathrm{CO} 421$ & Do & 1954 \\
\hline 209 & B 4744 & Do & 1963 & 236 & B 58230 & Do & 1970 & 267 & CO 434 & Do & 1970 \\
\hline 210 & В 4906 & Do & 1974 & 237 & В 59104 & Do & 1983 & 268 & $\mathrm{CO} 440$ & Do & 1963 \\
\hline 211 & В 49119 & Do & 1962 & 238 & В 59212 & Do & 1974 & 269 & CO 449 & Do & 1957 \\
\hline 212 & В 49224 & Do & 1974 & 239 & В 59250 & Do & Unknown & 270 & $\mathrm{CO} 453$ & Do & 1954 \\
\hline 213 & В 49388 & Do & 1974 & 240 & В 60125 & Do & 1974 & 271 & C120-78 & Cuba & 2003 \\
\hline 214 & B 50210 & Do & 1974 & 241 & В 60163 & Do & 1974 & 272 & CO 467 & Coimbatore & 1957 \\
\hline 215 & В 51116 & Do & 1970 & 242 & В 60267 & Do & 1974 & 273 & CO 475 & Do & 1956 \\
\hline 216 & В 51129 & Do & 1983 & 243 & В 6109 & Do & 1983 & 274 & CO 513 & Do & 1960 \\
\hline 217 & В 51131 & Do & 1970 & 244 & B 6113 & Do & 1983 & 275 & CO 617 & Do & 1960 \\
\hline 218 & B 51132 & Do & 1974 & 245 & В 62347 & Do & 1974 & 276 & CO 622 & Do & 1960 \\
\hline 278 & CO 677 & Coimbatore & 1970 & 308 & CO 1186 & Coimbatore & 1974 & 341 & CP69/1059 & 9 Canal point & 1983 \\
\hline 279 & CO 678 & Do & 1960 & 309 & CO 1190 & Do & 1987 & & & & \\
\hline 280 & CO 680 & Do & 1963 & 310 & CO 1198 & Do & 1987 & 343 & СР 70/321 & Do & 1983 \\
\hline 281 & CO 684 & Do & 1970 & 311 & CO 1202 & Do & 1987 & 344 & СР 71/396 & Do & 1983 \\
\hline 282 & CO 718 & Do & 1970 & 312 & CO 1208 & Do & 1987 & 345 & СР 71/421 & Do & 1983 \\
\hline 283 & CO 740 & Do & 1962 & 313 & CO 1230 & Do & 1974 & 346 & СР 1/441 & Do & 1983 \\
\hline 286 & CO 765 & Do & 1970 & 314 & CO 6023 & Do & 1974 & 347 & СР 71/443 & Do & 1984 \\
\hline 287 & CO 775 & Do & 1960 & 315 & CO 60191 & Do & Unknown & 348 & CP72/2083 & Do & 1983 \\
\hline 288 & CO 785 & Do & 1987 & 317 & СР 29/291 & Canal point & 1954 & 349 & СР 73/341 & Do & 1983 \\
\hline 289 & CO 798 & Do & 1963 & 318 & CP 29/320 & Do & 1953 & 350 & COS 109 & Unknown & 1965 \\
\hline 290 & CO 810 & Do & 1974 & 319 & СР 36/105 & Do & 1959 & 351 & COS 245 & Do & 1970 \\
\hline 291 & CO 842 & Do & 1974 & 321 & СР44/101 & Do & 1957 & 353 & COS 510 & Do & 1962 \\
\hline 292 & CO 853 & Do & 1974 & 323 & СР 47/193 & Do & Unknown & 354 & COK 30 & Do & 1970 \\
\hline 293 & CO 911 & Do & 1963 & 324 & СР 48/103 & Do & 1960 & 355 & D 42/58 & $\begin{array}{l}\text { Demerara } \\
\text { (Guyana) }\end{array}$ & 1974 \\
\hline 294 & CO 945 & Do & 1970 & 325 & СР 52/68 & Do & 1974 & 356 & D $141 / 46$ & Do & 1974 \\
\hline 295 & CO 954 & Do & 1987 & 326 & СР 53/18 & Do & 1974 & 357 & D 188/56 & Do & 1974 \\
\hline 296 & CO 957 & Do & 1965 & 327 & M202/46 & Mauritius & Unknown & 359 & DB 228/57 & Do & Unknown \\
\hline 297 & CO 961 & Do & 1970 & 328 & H48/4605 & Hawaii & 1965 & 360 & DB 377/60 & Do & 1974 \\
\hline 298 & CO 967 & Do & 1974 & 330 & H49/3533 & Do & 1974 & 361 & DB 386/60 & Do & 1974 \\
\hline 299 & CO 976 & Do & 1965 & 331 & M442/51 & Mauritius & Unknown & 362 & DB $414 / 60$ & Do & 1974 \\
\hline 300 & CO 991 & Do & 1963 & 332 & СР44/155 & Canal point & Unknown & 363 & DB 414/66 & Do & 1983 \\
\hline
\end{tabular}




\section{Continued}

\begin{tabular}{|c|c|c|c|c|c|c|c|c|c|c|c|}
\hline 301 & CO 997 & Do & 1967 & 333 & CP 71-400 & Do & Unknown & 364 & Ebene 1/37 & Unknown & 1957 \\
\hline 302 & CO 1001 & Do & 1970 & 334 & СР 60/23 & Do & 1974 & 365 & E 88/56 & Do & 1974 \\
\hline 303 & CO 1007 & Do & 1974 & 335 & СР 61/37 & Do & 1974 & 366 & E $188 / 53$ & Do & 1974 \\
\hline 304 & CO 1148 & Do & 1987 & 337 & M165/38 & Mauritius & unknown & 367 & E $188 / 56$ & Do & 1974 \\
\hline 305 & CO 1157 & Do & 1987 & 338 & CP 65/357 & Canal point & 1983 & 368 & F 134 & $\begin{array}{l}\text { Formosa, } \\
\text { (Taiwan) }\end{array}$ & 1970 \\
\hline 306 & CO 1158 & Do & 1987 & 339 & CP 8/1026 & Do & 1984 & 370 & Н 32/8560 & $\begin{array}{l}\text { Hawaii } \\
\text { (USA) }\end{array}$ & 1960 \\
\hline 307 & CO 1177 & Do & 1974 & 340 & CP68/1067 & Do & 1983 & 371 & Н 37/1933 & Do & 1960 \\
\hline 372 & CO-602 & Coimbatore & unknown & 398 & N 7 & $\begin{array}{c}\text { Natal } \\
\text { (South A.) }\end{array}$ & 1983 & 426 & NCD 349 & Unknown & 1970 \\
\hline 373 & Н 38/4443 & $\begin{array}{l}\text { Hawaii } \\
\text { (USA) }\end{array}$ & 1960 & 399 & N 8 & Do & 1983 & 427 & NCD 376 & Do & 1956 \\
\hline 374 & H 39/3633 & Do & 1960 & 400 & N 11 & Do & 1987 & 428 & NCO 382 & Do & 1965 \\
\hline 377 & H 44/2364 & Do & 1974 & 401 & N 14 & Do & 1980 & 429 & PR 905 & Puerto Rico & 1959 \\
\hline 378 & Н 44/3098 & Do & 1960 & 402 & N 50/93 & Do & 1965 & 430 & PR 980 & Do & 1965 \\
\hline 379 & $\begin{array}{l}\text { HY8RID } \\
\text { KS }\end{array}$ & Unknown & 1974 & 403 & SP70-1284 & Unknown & Unknown & 431 & PR 1000 & Do & 1960 \\
\hline 380 & L 60-14 & $\begin{array}{c}\text { Louisiana, } \\
\text { USA }\end{array}$ & 1974 & 404 & C86-12 & Cuba & 2003 & 432 & PR 1007 & Do & 1970 \\
\hline 381 & L 60-25 & Do & 1974 & 405 & Q 70 & Natal & 1965 & 433 & PR 1013 & Do & 1970 \\
\hline 382 & L 60-35 & Do & Unknown & 406 & R 48/3166 & $\begin{array}{l}\text { Reunion } \\
\text { Island, } \\
\text { (France) }\end{array}$ & Unknown & 434 & PR 1059 & Do & 1974 \\
\hline 383 & L 60-40 & Do & 1974 & 407 & TDRJAN & Australia & 1956 & 435 & $\begin{array}{c}\text { PPQK } \\
1604\end{array}$ & Do & 1958 \\
\hline \multirow[t]{2}{*}{384} & M 31/45 & Mauritius & 1957 & 408 & C90-501 & Cuba & 2003 & 436 & PDJ 28/78 & $\begin{array}{c}\text { Proefstation } \\
\text { Cost Java } \\
\text { (Indonesia) }\end{array}$ & Unknown \\
\hline & & & & 409 & WD II & $\begin{array}{c}\text { Local } \\
\text { collection }\end{array}$ & 1953 & 437 & Pindar & Unknown & 1957 \\
\hline 385 & M 53/263 & D0 & Unknown & 410 & $\begin{array}{l}\text { Yellow } \\
\text { Cane }\end{array}$ & Unknown & Unknown & 439 & Q 50 & $\begin{array}{l}\text { Queens land } \\
\text { (Austaralia) }\end{array}$ & 1957 \\
\hline 386 & M 112/34 & Do & 1960 & 412 & C86-165 & Cuba & 2003 & 440 & SP70-1284 & Unknown & Unknown \\
\hline 388 & M 147/44 & Do & 1957 & 415 & S 17 & Unknown & Do & 441 & B80-505 & Barbados & Unknown \\
\hline 389 & M 377/5 & Do & Unknown & 417 & SP70-1284 & Unknown & Unknown & & & & \\
\hline 390 & Mex 52/29 & Mexico & 1970 & 418 & N 51/168 & Natal & 1974 & & & & \\
\hline 391 & $\begin{array}{c}\text { Mex } \\
53 / 142\end{array}$ & Do & 1970 & 419 & N 51/539 & Do & 1974 & & & & \\
\hline 392 & $\begin{array}{c}\text { Mex } \\
54 / 245\end{array}$ & Do & 1970 & 420 & N 52/219 & Do & 1974 & & & & \\
\hline 393 & $\begin{array}{c}\text { Mex } \\
54 / 255\end{array}$ & Do & 1970 & 421 & N 53/216 & Do & 1974 & & & & \\
\hline 394 & $\begin{array}{c}\text { Mex } \\
57 / 197\end{array}$ & Do & 1970 & 422 & N 55/805 & Do & 1983 & & & & \\
\hline
\end{tabular}




\begin{tabular}{cccccccc}
\multicolumn{2}{l}{ Continued } \\
\hline 395 & B80-250 & Barbados & Unknown & 423 & NCD 310 & Do & 1953 \\
396 & $\begin{array}{c}\text { Mex } \\
59 / 1828\end{array}$ & Mexico & 1983 & 424 & NCO 334 & Do & 1962 \\
397 & N 6 & $\begin{array}{c}\text { Natal } \\
\text { (South A.) }\end{array}$ & 1983 & 425 & $93-V 1$ & Unknown & Unknown \\
\hline
\end{tabular}

\section{Submit or recommend next manuscript to SCIRP and we will provide best service for you:}

Accepting pre-submission inquiries through Email, Facebook, LinkedIn, Twitter, etc.

A wide selection of journals (inclusive of 9 subjects, more than 200 journals)

Providing 24-hour high-quality service

User-friendly online submission system

Fair and swift peer-review system

Efficient typesetting and proofreading procedure

Display of the result of downloads and visits, as well as the number of cited articles

Maximum dissemination of your research work

Submit your manuscript at: http://papersubmission.scirp.org/ 